\title{
Structural, Petrological and Thermal Evolution of a Tertiary Ductile Strike-Slip Shear Zone, Diancang Shan, Yunnan
}

\author{
P.H. Leloup,${ }^{1}$ T. Mark Harrison, ${ }^{1}$ F.J. Ryerson, ${ }^{2}$ Chen WenjI, ${ }^{1}$ Li QI,${ }^{1}$ \\ P. TAPPonnier, ${ }^{3}$ and R. LACASSIN ${ }^{3}$
}

\begin{abstract}
The Diancang Shan, a horst massif within the Red River fault zone in Yunnan, People's Republic of China, preserves a structural, petrological, and thermal record of two distinct phases of tectonic activity: a left-lateral ductile shear that terminated between 20 and $17 \mathrm{Ma}$ and a ductile-to-brittle phase of normal faulting which began at $4.7 \mathrm{Ma}$ and remains active. Mylonitic rocks in the core of the range display an early, steep, hightemperature (HT), Bchistosity and a horizontal stretching lineation that are both parallel to the trend of the belt. Kinematic indicators indicate that shear was left-lateral. The complex shape of the HT schistosity at the southern termination of the massif likely results from a large-scale, oblique, left-lateral C' shear plane that dismembered the shear zone and separated the Ailao Shan and the Diancang Shan as left-lateral deformation terminated. Thermochronological and thermobarometric results suggest that the gneisses were partially unroofed during this event. Along the eastern edge of the Diancang Shan, the HT fabrics were overprinted by low-temperature structures during activation of east dipping normal faults. Cooling associated with this normal/right-lateral faulting along the Diancang Shan (and perhaps activation of the right-lateral/normal movement on the Range Front fault farther south along the Ailao Shan) began at 4.7 $\pm 0.1 \mathrm{Ma}$. These results tend to support the view that extrusion of Indochina occurred along the left-lateral Red River shear zone between 35 and 19-17 Ma. Initiation of right-lateral/normal slip during the late Miocene may relate to eastward extensional collapse of the thickened Tibetan crust or, more probably, to initiation of the second phase of extrusion.
\end{abstract}

\section{INTRODUCTION}

Advocates of the view that continental extrusion has been an important mechanism in accommodating IndoAsian convergence since collision began at about $50 \mathrm{Ma}$ identify a number of structures along which the postulated strike-slip motion occurred during the first phase of extrusion [e.g., Tapponnier et al., 1986]. The most emphasized of these features is the Red River fault zone, an impressive geological feature that can be traced for over $1000 \mathrm{~km}$ from Tibet through Yunnan to the South China Sea (Figure 1). However, those skeptical of a prominent role for continental extrusion early in collision [e.g., Dewey et al., 1989] point out that slip on the presently active Red River fault is right-lateral [see Tapponnier and Molnar, 1977; Allen et al., 1984], the opposite sense of motion to that required for extrusion of southeastern Asia. Still others view the gneissic core of the Red River fault zone as strictly a Proterozoic [e.g., Fan, 1986; Cheng, 1987], Paleozoic [e.g., Helmcke, 1985; Wang and Chu, 1988], or Triassic suture [e.g., Fan, 1978; Klimetz, 1983; Sengor, 1987; Hutchinson,

\footnotetext{
${ }^{1}$ Department of Earth and Space Sciences and Institute of Geophysics and Planetary Physics, University of California, Los Angeles.

2Institute of Geophysics and Planetary Physics, Lawrence Livermore National Laboratory, Livermore, California.

${ }^{3}$ Institut de Physique du Globe de Paris.
}

Copyright 1993 by the American Geophysical Union.

Paper number 92JB02791.

0148-0227/93/92JB-02791\$05.00
1989] along which the Proterozoic South China basement has been thrust to the southwest over the Indochina sedimentary series [e.g., Duan and Zhao, 1981; Cheng, 1987].

In the continental extrusion hypothesis, the South China Sea is interpreted to be a pull-apart basin at the southeast termination of the Red River shear zone (Figure 1) that opened as a result of left-lateral strikeslip motion [Tapponnier et al., 1982, 1986; Peltzer and Tapponnier, 1988]. Calculation of poles of rotation and rates of seafloor spreading based on seafloor magnetic anomalies suggest a total left-lateral offset along the Red River shear zone of about $550 \mathrm{~km}$ between 32 and $\sim 16 \mathrm{Ma}$ [Briais, 1989; Briais et al., 1993]. Recent studies have tended to confirm many of the predictions of the extrusion model and support the interpretation that the Red River fault zone is a Tertiary, intracontinental, ductile, strike-slip shear zone with at least $500 \mathrm{~km}$ of left-lateral offset [Tapponnier et al., 1990; Schärer et al., 1990, Leloup et al., 1990; Lacassin et al., 1991; Harrison et al., 1992a]. This fault alone may have absorbed up to $\sim 20 \%$ of the collision-related deformation affecting Asia [Lacassin et al., 1991; Leloup, 1991].

The three 10- to 20-km-wide massifs in southern Yunnan that define the Red River shear zone, the Ailao Shan, Diancang Shan, and Xuelong Shan (the ADX shear zone), consist of highly deformed metamorphic rocks that show consistent evidence of early left-lateral ductile shear [e.g., Tapponnier et al., 1990; Leloup et al., 1990] (Figure 1). Subsequently, the sense of movement on this fault zone has changed to have right-lateral slip combined in places with normal throw [Tapponnier and Molnar, 1977; Allen et al., 1984; Harrison et al., 1992a]. 


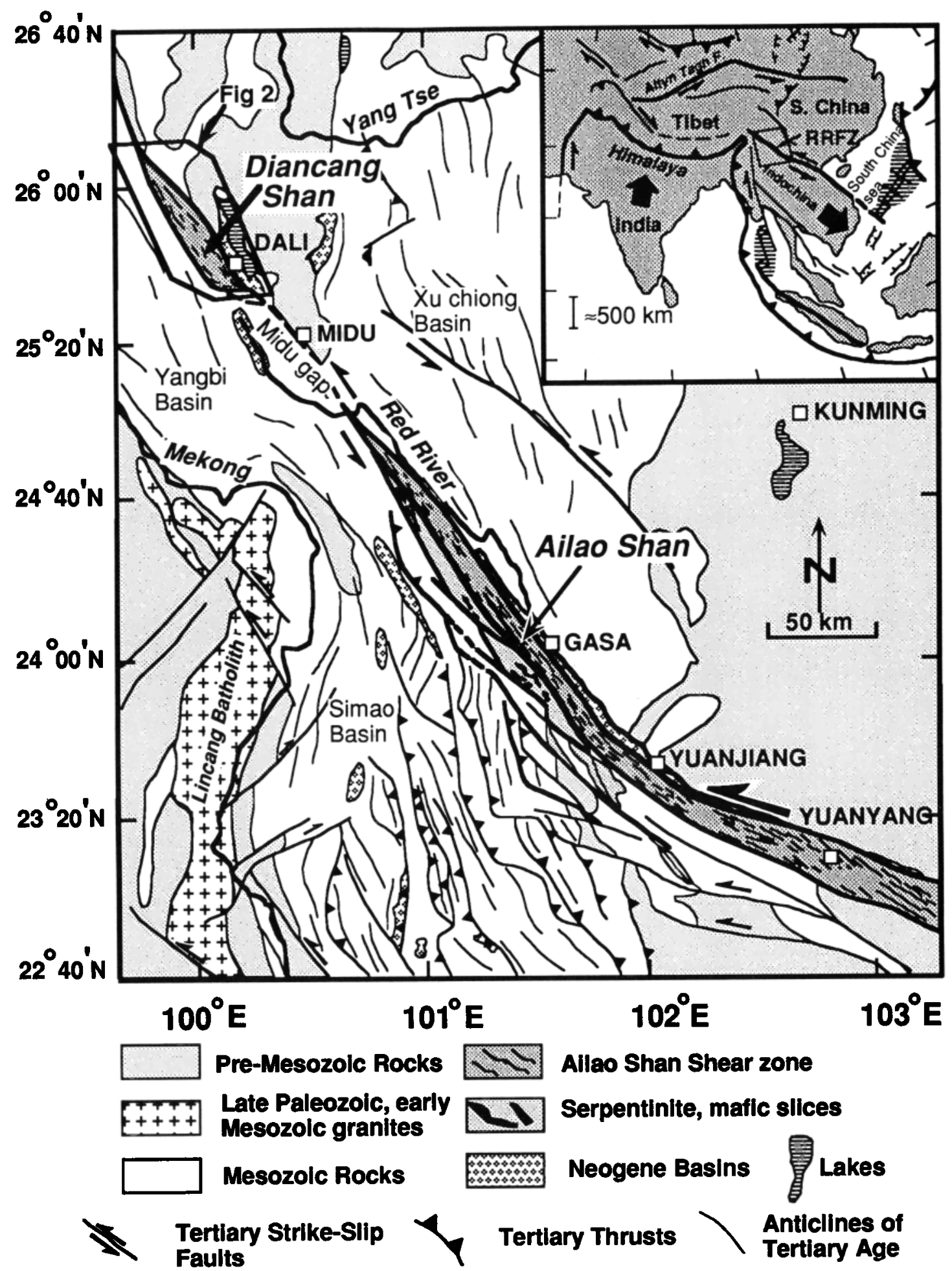

Fig. 1. Map of the post-Cretaceous tectonics of Yunnan province showing the Ailao Shan and Diancang Shan ranges. Mesozoic and Tertiary cover rocks are shown without pattern or shading. Inset is map of southeastern Asia showing pre-Pliocene Tertiary tectonic features of the Indo-Asian collision zone including the Red Hiver fault zone (RRFZ). Shaded areas are Tertiary seafloor [from Tapponnier et al., 1990].

In this paper we focus on the geological evolution of the Diancang Shan, a horst bounded massif to the northwest of the Ailao Shan range (Figure 1). We have investigated aspects of the structural, petrological, and thermal evolution of this range using recently develo- ped geological, geochemical and geochronological tools [Berthé et al., 1979a,b; Spear and Selverstone, 1983; Lovera et al., 1989] in order to address three questions. When did ductile shearing end and when did normal faulting (and presumably deposition of the adja- 
cent basin fill) begin? What was the geothermic structure prior to, during, and following deformation? Is the structural history of the Diancang Shan related to or separate from the Ailao Shan? Our structural observations and pressure-temperature-time (P-T-t) results appear to answer, or at least place constraints on, all these outstanding issues.

\section{ANalytical Methods}

\section{Thermobarometry}

Mineral analyses were performed on a fully automated JEOL-733 electron microprobe operating at an accelerating voltage of $15 \mathrm{kV}$. Beam current varied between 5 and $10 \mathrm{nA}$ depending upon mineral type (e.g., 5 nA for feldspars, $10 \mathrm{nA}$ for garnet) using a beam rastered over a $5 \mu \mathrm{m}$ × $5 \mu \mathrm{m}$ area for beam sensitive minerals (e.g., feldspars) and $1 \mu \mathrm{m} \times 1 \mu \mathrm{m}$ for others. Mineral standards were used and the $\mathrm{X}$-ray intensities were reduced using the correction procedures of Bence and Albee [1968] with correction factors from Albee and Ray [1970].

\section{${ }^{40} \mathrm{Ar} /{ }^{\mathrm{B}} \mathrm{Ar}$}

$\mathrm{K}$-feldspar, hornblende, biotite, and white mica mineral separates were obtained using heavy liquid and magnetic separatory techniques from fresh hand specimens. Approximately $15 \mathrm{mg}$ each of $\mathrm{K}$-feldspar and hornblende and $5 \mathrm{mg}$ of mica were wrapped in Sn foil and sealed in 6-mm ID evacuated quartz glass vials together with Fish Canyon sanidine (FC-3) flux monitors and irradiated for 32.1 hours in the H-5 position of the Ford Reactor, University of Michigan (see Harrison et al. [1992a] for irradiation details). Five aliquants of monitor crystals were individually fused and analyzed for their argon isotopic composition. The pooled ${ }^{40} \mathrm{Ar} /{ }^{39} \mathrm{Ar}_{K}$ results yielded $\mathrm{J}$ factors between 0.005134 and 0.005192 , assuming an age of $27.8 \mathrm{Ma}$ for FC-3 [Miller et al., 1985]. Vacuum-fused $\mathrm{K}_{2} \mathrm{SO}_{4}$ was also included in the tube. Correction factors used for interfering neutron reactions were $\left({ }^{40} \mathrm{Ar} /{ }^{39} \mathrm{Ar}\right)_{K}=0.026$ $( \pm 3 \%),\left({ }^{39} \mathrm{Ar} /{ }^{37} \mathrm{Ar}\right)_{C_{\alpha}}=7.0 \times 10^{-4}$ and $\left({ }^{36} \mathrm{Ar} /{ }^{37} \mathrm{Ar}\right)_{C_{\alpha}}=$ $2.3 \times 10^{-4}$.

All samples were step-heated in a Ta crucible within a double-vacuum furnace [see $M c D o u g a l l$ and Harrison, 1988], but the K-feldspar was heated in the cyclic fashion described by Harrison et al. [1992a] to enhance retrieval of kinetic information. Argon blanks over the course of these analyses averaged $1.7 \times 10^{-16} \mathrm{~mol}{ }^{40} \mathrm{Ar}$ in an atmospheric ratio. ${ }^{40} \mathrm{Ar} /{ }^{39} \mathrm{Ar}$ isotopic measurements were made using a VG 1200 S automated mass spectrometer operated in the electron multiplier mode. A correction for mass discrimination of $0.13 \% / a-$ $\mathrm{mu}$ was made to the isotope ratios based on analysis of atmospheric argon. Overall sensitivity for the spectrometer during these analyses was $1.1 \times 10^{-17} \mathrm{~mol}$ $\mathrm{Ar} / \mathrm{mV}$. Further details of the experimental procedures are given by Harrison et al. [1992a] and details of peak height measurements and calculation of associated uncertainties are given by McDougall and Harrison [1988]. All analytical results are held in radon.ess.ucla.edu
(128.97.31.46) in directory pub/tables/dian and can be obtained directly from the anonymous account via $\mathrm{ftp}$.

\section{Geological Setting}

\section{The Red River Tertiary Ductile Left-Lateral Shear Zone}

The Red River shear zone separates regions with different stratigraphy and structural trends: the Yangtze platform, or South China block, to the north, and the Indochina, or Khorat-Kontum, block to the south (Figure 1). At present, an active fault with both rightlateral slip and normal throw [Allen et al., 1984] follows the edges of narrow gneissic belts (the Day-Nui-Con-Voi in Vietnam, and the ADX in Yunnan province). These belts are interpreted to be portions of a single large shear zone [e.g., Tapponnier et al., 1986, 1990, Leloup, 1991, Leloup et al., 1990].

The very long $(\sim 400 \mathrm{~km})$ and narrow $(\sim 10-20 \mathrm{~km})$ metamorphic belt exposed in the Ailao Shan is presently the best studied of the ranges. Most rock types in the gneiss cores are mylonitic, and the schistosity is generally steep and always parallel to the strike of the belt [e.g., Tapponnier et al., 1990]. Stretching lineations are clear and always nearly horizontal. There is numerous and unambiguous evidence from noncoaxial deformation and kinematic indicators for a left-lateral sense of shear [e.g., Tapponnier et al., 1990; Leloup, 1991]. Restoration of amphibolitic layer boudinage indicates a finite elongation of $\sim 700 \%$ indicating a minimum total offset of $\sim 300 \mathrm{~km}$ along the shear zone [Lacassin et al., 1991,1993]. Ages from late syntectonic anatectic leucogranite pods parallel to the schistosity and affected by left-lateral shear cluster between 23 and 24 Ma [Schärer et al., 1990]. Measurements of elongation of such leucogranite layers suggest that $\sim 80 \mathrm{~km}$ of the total ductile displacement could have occurred after $23 \mathrm{Ma}$ [Laccasin et al., 1993]. Thermobarometric measurements suggest a very high geothermal gradient $\left(\sim 40^{\circ} \mathrm{C} / \mathrm{km}\right)$ during at least part of the left-lateral deformation [Leloup and Kienast, 1993]. ${ }^{40} \mathrm{Ar} /{ }^{39} \mathrm{Ar}$ results have been interpreted as indicating that ductile leftlateral deformation terminated between 22-19 Ma, with subsequent oblique unroofing probably occurring along the normal Range Front fault that follows the northeast edge of the massif [Harrison et al., 1992a].

The Diancang Shan is an elongated metamorphic massif (about $15 \mathrm{~km}$ wide and $80 \mathrm{~km}$ long) with a long crest of summits over $3500 \mathrm{~m}$ (and as high as $4122 \mathrm{~m}$ ) in a region with an average elevation of $2200 \mathrm{~m}$. The Diancang Shan and Ailao Shan massifs are separated by almost $80 \mathrm{~km}$ of essentially unmetamorphosed sedimentary rocks that are deformed in a brittle fashion. This section of the Red River shear zone was termed the "Midu Gap" by Tapponnier et al. [1990]. Aligned with these two uplifted gneissic cores is a third metamorphic massif, the Xuelong Shan ("mountain of the snow dragon"), located $110 \mathrm{~km}$ to the northwest of the Diancang Shan. In this range, most of the rocks are mylonitic, the schistosity is less steep but still parallel the trend of the belt, the stretching lineation is horizontal, and many shear criteria indicate a left-lateral sense of shear [Leloup et al., 1990; Leloup, 1991]. 


\section{Geology of the Diancang Shan}

The Diancang Shan sits between Paleozoic to Mesozoic cover rocks and active normal faulting has led to the formation of Neogene-Quaternary basins on both sides of the horst (Figures 1 and 2) [Bureau of Geology and Mineral Resources of Yunnan, 1983]. To the west of the Diancang Shan is the Yangbi basin, mostly composed of Triassic to Eocene sandstones affected by approximately northwest-southeast trending folds (Figure 1). To the east, the cover rocks are principally Devonian limestones and Permian pillow basalts locally intruded by granites and scattered mafic bodies (norites?) (Figure 2). In the northeastern part of the Diancang Shan, Devonian limestones are mapped as lying stratigraphically above the metamorphic rocks (Figure 2) [Bureau of Geology and Mineral Resources of Yunnan, 1983].

The eastern and western flanks of the Diancang Shan have steep slopes with an average grade of $\sim 20^{\circ}$ (Figures $3 b, 3 e$, and 4 ). The eastern flank exhibits triangular shaped facets [Armijo et al., 1986] separated by deep canyons (Figures $3 a$ and $3 b$ ) and is bounded by the Lake Er Hai sedimentary basin, the largest NeogeneQuaternary basin in this area (Figure 2). Holocene sediment thicknesses average between 170 and $500 \mathrm{~m}$, and the total thickness of Neogene-Quaternary sediments in the basin is estimated to be $2200 \mathrm{~m}$ (Figure 3c) [Guo et al., 1986]. These observations indicate that the eastern flank of the Diancang Shan corresponds to an active east-dipping normal fault (Figure 2) [Tapponnier and Molnar, 1977; Allen et al., 1984] and the thick basin sediments result from rapid erosion of the uplifted Diancang Shan [Guo et al., 1986; Tapponnier et al., 1990]. On SPOT images, the fault appears to exhibit a rightlateral, en echelon pattern (Figure $3 a$ ).

The western flank of the Diancang Shan also exhibits evidence of active normal faulting but is not bounded by a large basin. At the northern extremity of the Diancang Shan, triangular shaped facets [Armijo et al., 1986] are clear both in the field [Allen et al., 1984] and on SPOT images (Figures $3 d$ and $3 e$ ). In addition, remnant Neogene sediments at the base of the flank are affected by small normal faults. Canyons that cut more than $300 \mathrm{~m}$ through the gneisses attest to recent uplift. Detailed mapping of these normal faults shows that the Diancang Shan range is also bounded to the west by en echelon, north-northwest trending, normal faults (Figures 2 and $3 d$ ). The contrast in morphology between the eastern and the western foothills of the Diancang Shan appears to be related more to the efficiency of the drainage on each side of the range rather than the activity of normal faulting.

The southern portion of the Diancang Shan is thus a classic horst structure bounded by two parallel normal faults with opposite dips. In the northern end of the massif the structure is more complex with minor parallel normal faults affecting the primary horst (Figure 2). South of the Diancang Shan horst, near Midu, the Red River active fault system is composed of two small grabens. Farther south it becomes purely strike-slip until the northern tip of the Ailao Shan massif where it again begins to show evidence of normal throw [Allen et al., 1984; Leloup, 1991].

\section{Structure and Deformation of The Metamorphic Rocks}

Four sections across the Diancang Shan have been studied in detail. The first (zone A, Figure 2) is located in a valley at the southern extremity of the range. The second (section B, Figure 2) is located to the west of Dali and reaches the summit of the Diancang Shan. The third (section C, Figure 2) is located in a deep canyon which incises the western flank of the Diancang Shan, and is nearly aligned with section $B$. The fourth (section D, Figure 2) is located in a valley which crosscuts the northern end of the Diancang Shan metamorphic massif. Structures seen along sections B, C, and D are easily explained by an event of left-lateral strike-slip deformation and are described by Tapponnier et al. [1990] and Leloup [1991]. In this paper we focus essentially on the structures seen at the southern end of the massif adjacent to our thermobarometric results.

\section{Macroscopic Structures}

The Diancang Shan massif is composed of various rock types including marbles, paragneisses, augengneisses, skarns, leucogranitic layers, mica schists, and hornblende schists. Nearly all these metamorphic rocks show typical mylonitic textures [Higgins, 1971; Hobbs et al., 1976; Bell and Etheridge, 1973]. They usually exhibit a strong schistosity marked by the orientation of biotite, quartz, and/or feldspar ribbons (Figures $5 a, 5 b, 5 f$, and $5 g$ ). This schistosity bears a prominent lineation which usually corresponds to a stretching and mineral lineation marked by the elongation of quartz and feldspar ribbons, tails on porphyroclasts, and the alignment of metamorphic minerals (biotite, amphibole, and tourmaline) (Figures $5 a, 5 b$, and $5 e$ ). In some places, sheath folds and folds with axes parallel to the lineation, typical of highly strained rocks [Quinquis et al., 1978; Cobbold and Quinquis, 1980; Lacassin and Mattauer, 1985], affect the mylonitic banding. Boudinage structures are widespread and affect both the mylonitic banding formed during earlier deformation stages and leucocratic veins emplaced during deformation,. The corresponding stretching direction is always parallel to the lineation. These relatively hightemperature structures will be termed as "HT structures" in the rest of the text.

Locally retrograde, lower temperature structures (LT) defined by chlorite or sericite are found together with the HT structures. Along section B, the HT schistosity is locally overprinted by chlorite slickensides (Figure 6a) and chlorite fault gouge is found between gneiss slabs (Figure 6b). Near the mouth of the gorge west of Xiaguan (sites A1 and A2, Figure 2), both schistosity and lineation in mylonites are marked by chlorite and sericite.

\section{Schistosity Attitude}

In section $B$, along the eastern limb of the Diancang Shan, the schistosity is either vertical or dips steeply toward the east-northeast. On the western limb (section $C$ ), it dips $50^{\circ}$ on the average toward the westsouthwest (Figures 4a, and 7). In both cases the schis- 

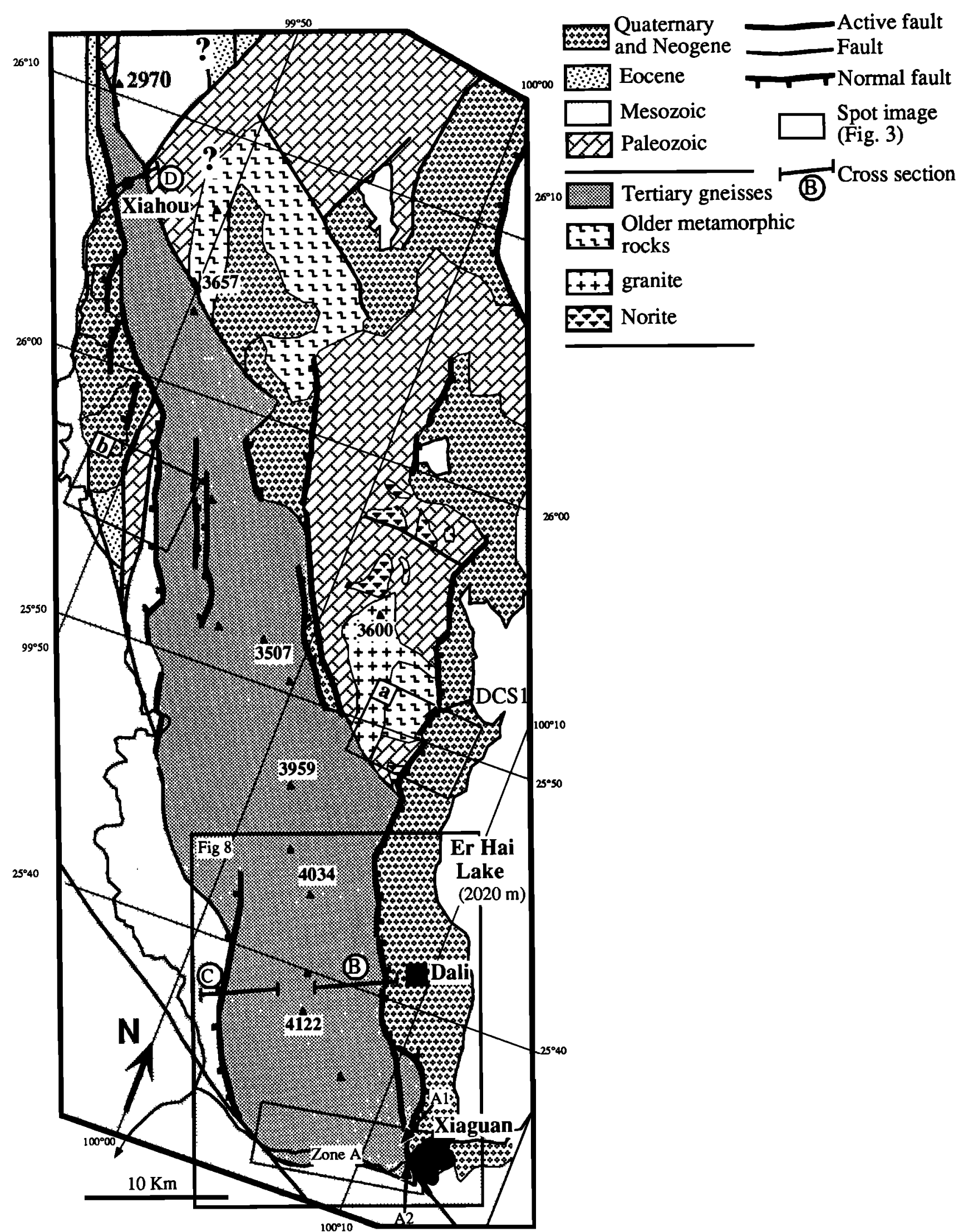

Fig. 2. Simplified geological map of the Diancang Shan region. Geology is drawn from the geological map of Yunnan, scale 1/500,000, modified observations and SPOT image interpretation. Traces of active faults are inferred from the morphology (detailed topographic maps and SPOT image interpretation). Elevations are in meters and taken from topographic maps at a scale of $1 / 100,000$. Lines $A, B, C$, and D show cross section locations. Boxes $a$ and $b$ correspond to parts of SPOT image K.J. 255-298 shown in Figure $3 a$ and $3 d$, respectively. 

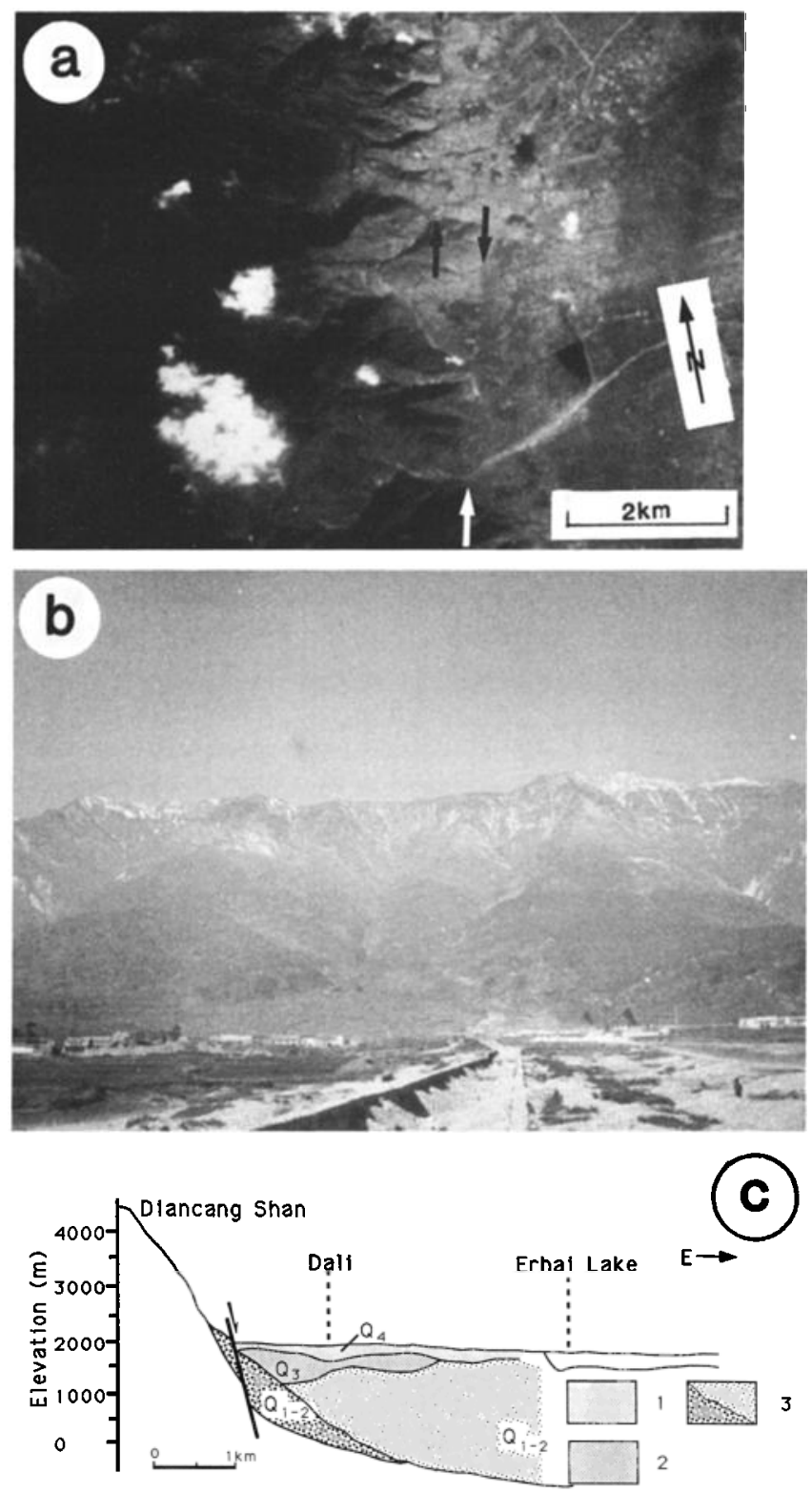

Fig. 3. Active faults bounding the Diancang Shan. (a) En echelon pattern of the normal fault on the eastern flank of the Diancang Shan (frame a in Figure 2). Arrows indicate the fault traces. (b) Photography of the triangular-shaped facets near Dali at the level of the section B, view toward the east-southeast. (c) Cross section of the Quaternary Er Hai Basin [from Guo et al., 1986]. (d) En echelon pattern of the normal fault on the northwestern flank of the Diancang Shan (frame b in Figure 2). Arrows indicate the fault traces. (e) View of the triangular-shaped facets of the northeastern flank of the Diancang Shan corresponding to Figure 3d, view toward the south.

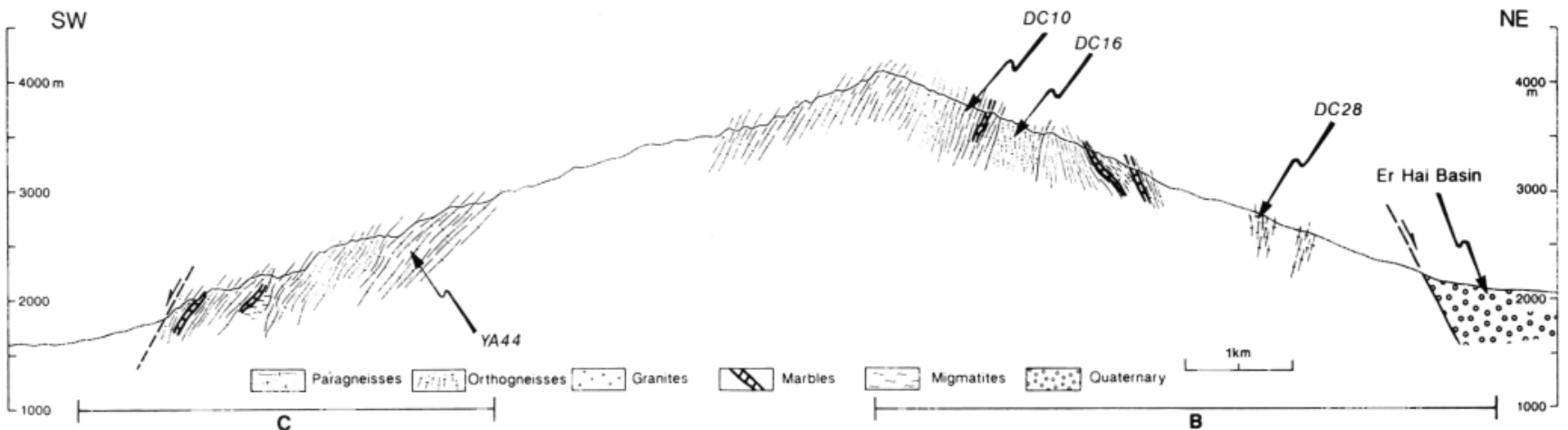

Fig. 4. Geological cross section of the core of the Diancang Shan (sections B and C) and location of samples DC10, 16, YA44, and 28. Drawn from field observations and topographic maps at scale $1 / 100,000$ (elevation in meters). 

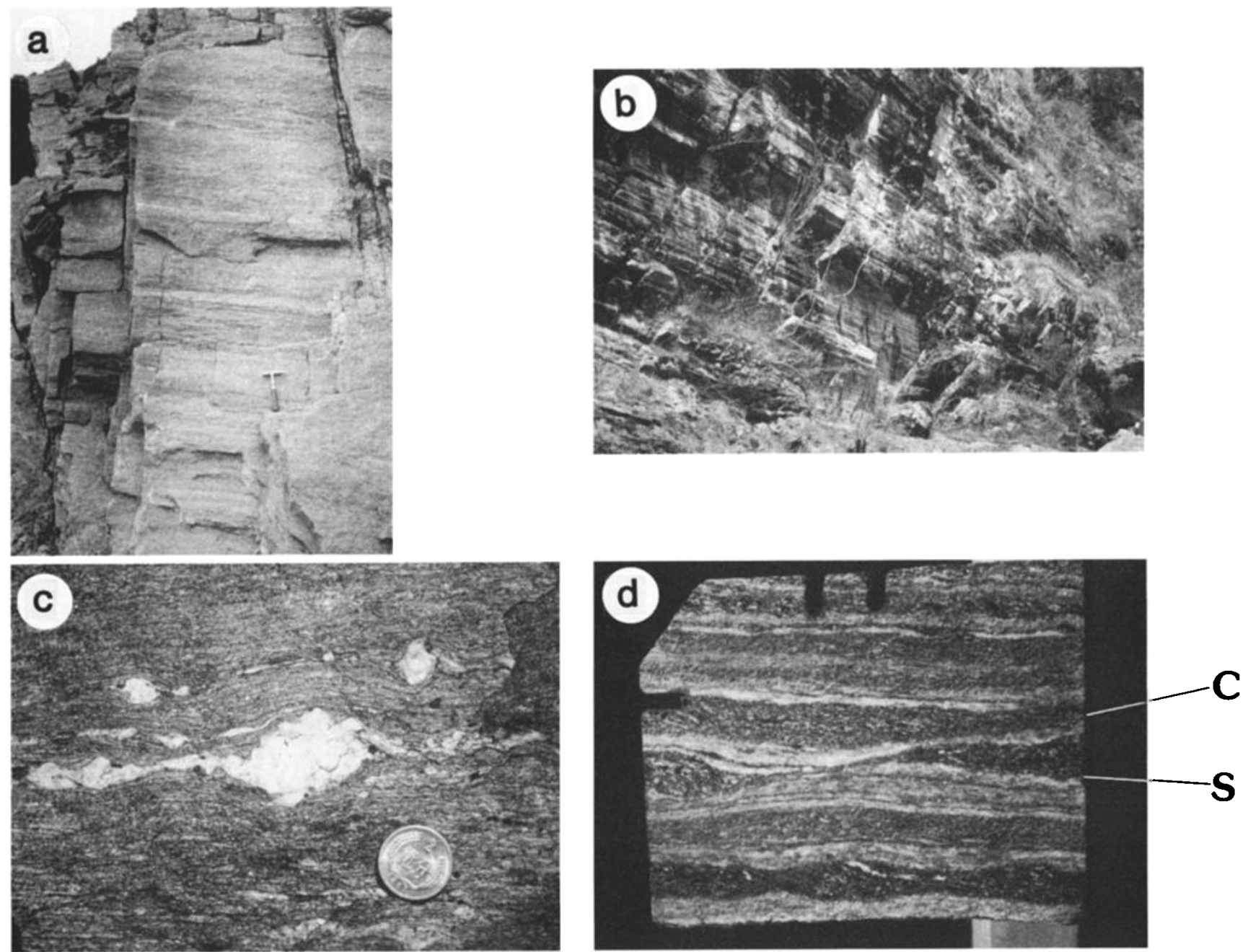

Fig. 5. (Opposite) Ductile deformation in the Diancang Shan (zone A and sections B and C). (a) Slabs of steeply dipping gneisses with subhorizontal lineation (pitch $12^{\circ} \mathrm{N}$ ) on the northeast flanks of the range (section B), viewed towards the southwest. (b) Steeply dipping schistosity and subhorizontal lineation (pitch $15^{\circ} \mathrm{N}$ ) on the southwest flanks of the range (section $\mathrm{C}$ ), viewed towards the west. (c) Rolling structures on feldspar porphyroclasts in mylonitic gneisses along section $B$. The section, viewed from above, is perpendicular to the schistosity and parallel to the lineation. Shape of the tails indicate a left-lateral sense of shear [Van Den Driessche and Brun, 1987]. (d) Polished slab of sample YA44 of section C showing left-lateral C-C' shear planes [Berthé et al., 1979a, b]. Section is perpendicular to the schistosity and parallel to the lineation, viewed from above. Note that schistosities corresponding to Figures $5 c$ and $5 d$ have opposite dip. (e) HT schistosities and mineral and stretching lineations in zone $A$, viewed from above. The direction $\mathrm{N} 120^{\circ}$ corresponds to the right side of the picture. Note the boudinage of the centimeter-scale tourmaline at the bottom of the picture. $(f)$ Oblique shear planes and asymmetric feldspar porphyroclast indicating top to the southeast directed shearing on the HT structures in zone A [e.g., Simpson and Schmidt, 1983]. Vertical section, parallel to the lineation, southeast at the left of the picture. (g) LT schistosity at the eastern extremity of the section A (site A2). View is toward the northwest. (h) Sketch showing asymmetric feldspar porphyroclasts indicating a top to the east directed shearing on the LT schistosity (normal fault). Vertical section, parallel to the lineation (site A2).

tosity is always parallel to the trend of the belt $\left(\mathrm{N} 165^{\circ}\right.$ on the average) (Figure 7 ). In section $D$, the metamorphic rocks are only exposed in a zone approximately 2.5 $\mathrm{km}$ wide and their schistosity strikes on average $\mathrm{N} 145^{\circ}$.

Toward the southwest of the Diancang Shan, the schistosity wraps around the corner of the massif, dips gently $\left(\sim 35^{\circ}\right)$ toward the south-southeast at the southern termination of the massif and even to the eastnortheast at the southeasternmost corner of the massif
(Figure 8). A detailed study of the schistosities along section A shows that the HT schistosities defined by biotite have significantly different orientations than the LT ones outlined by retrograde minerals (chlorite and sericite). The HT schistosities along section A show various strikes between $\mathrm{N}^{\circ} 0^{\circ}$ and $\mathrm{N} 100^{\circ}$ but all dip approximately $30^{\circ}$ to the south or the southeast (Figure 8) and have a common intersection striking $\mathrm{N} 118^{\circ}, 25^{\circ} \mathrm{E}$ with a maximum angular deviation (MAD) of $26^{\circ}$ (Fig- 

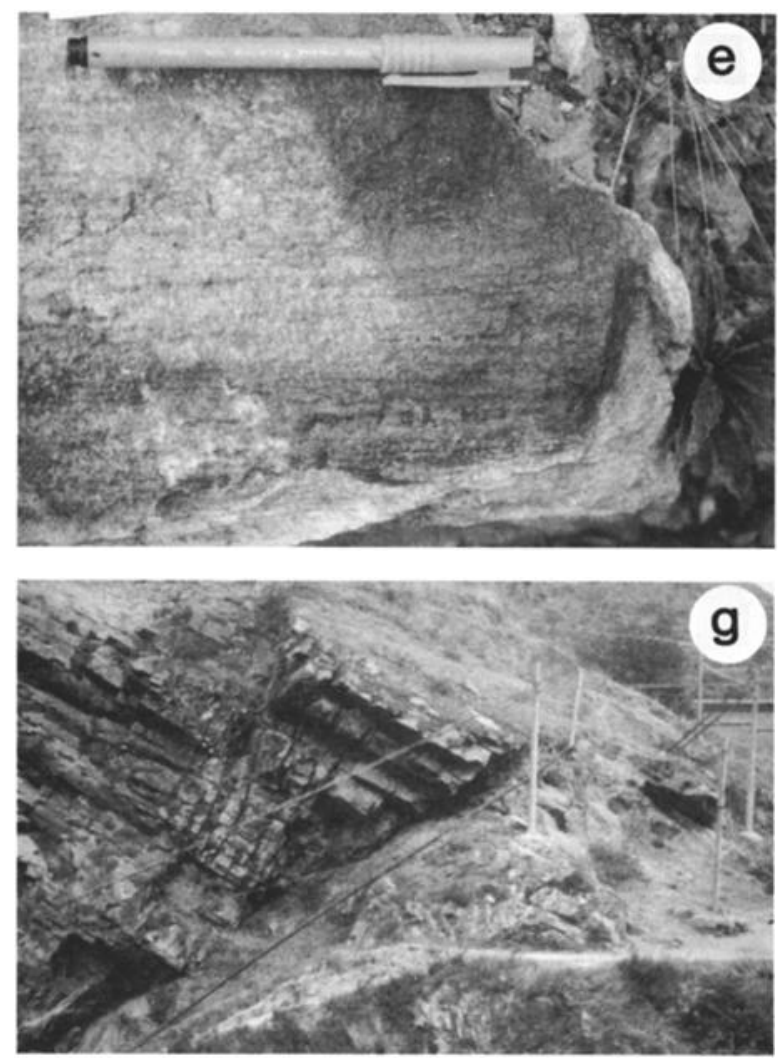

Fig. 5. (continued)
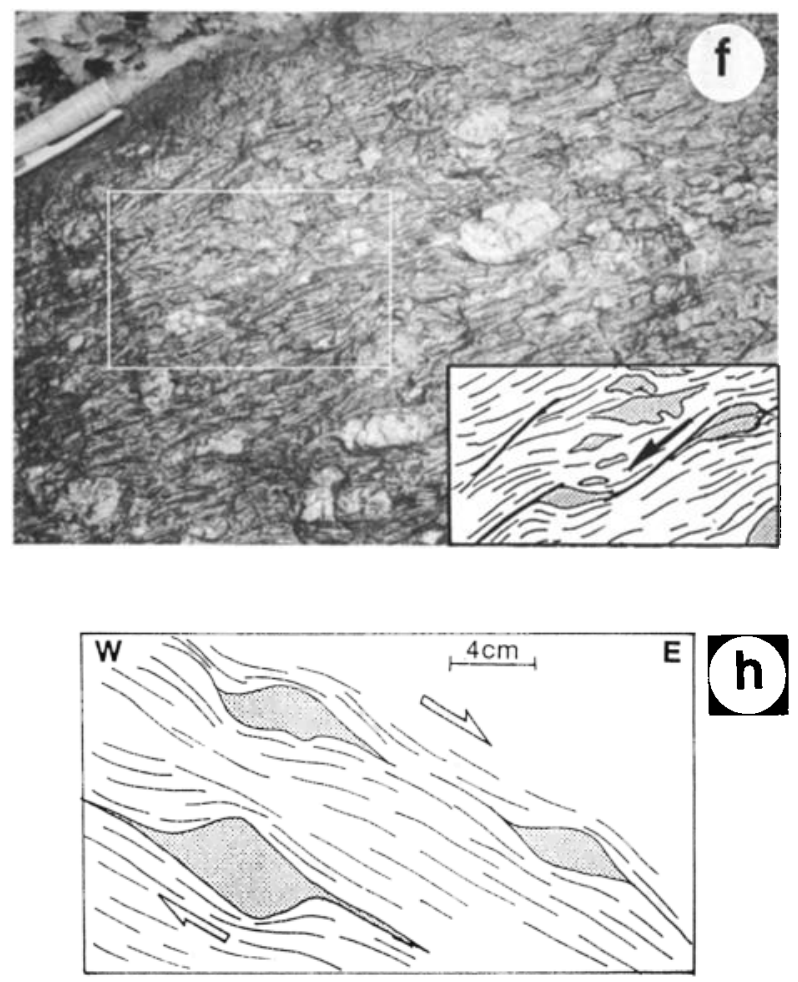

ure 9a). The Fisherian average of the schistosity poles is $\mathrm{N} 166^{\circ}, 60^{\circ} \mathrm{N}\left(k=30.4 ; \alpha_{95}=5.7^{\circ}, 23\right.$ data $)$. LT schistosities (sites A1 and A2) strike from N140 ${ }^{\circ}$ to $\mathrm{N} 175^{\circ}$ and dip toward the east $\left(\mathrm{N} 160^{\circ}, 37^{\circ} \mathrm{E}\right.$ on the average) (Figure 8 and $9 a$ ). The Fisherian average of the schistosity poles is $\mathrm{N} 74^{\circ}, 53^{\circ} \mathrm{W}\left(k=36.5, \alpha_{95}=5.8^{\circ}, 18 \mathrm{data}\right)$ at site $\mathrm{A} 1$ and $\mathrm{N} 60^{\circ}, 54^{\circ} \mathrm{W}\left(k=74.4, \alpha_{95}=5.6^{\circ}, 11\right.$ data $)$ at site A2. A statistical test. [McFadden and McElhin$n y, 1990$ ] indicates that the LT schistosities (sites A1 and A2) have a significantly different orientation than the HT ones (Figure 9c). In the field, the LT schistosity appears to crosscut the HT fabric (Figures $9 d$ and $9 e$ ).

In the eastern foothills $30 \mathrm{~km}$ to the north of Xiaguan (site DCS1, Figure 2), the schistosity (which strikes $\mathrm{N} 21^{\circ}, 31^{\circ} \mathrm{E}$ ) is marked by chlorite, muscovite, and quartz ribbons. Permian limestone is mapped unconformably overlying the schists [Bureau of Geology and Mineral Resources of Yunnan, 1983] in the region, but we could not verify this relationship.

\section{Lineation Attitude}

Despite the relative complexity of the schistosity geometry, the trend of HT lineations remains nearly constant and approximately parallel to the trend of the belt (Figure 8). HT lineations are almost horizontal in the massif core and on average strike and dip $\mathrm{N} 163^{\circ}$, $13^{\circ} \mathrm{N}$ along sections $\mathrm{B}$ and $\mathrm{C}$ (Figures 7 , and 8 ), and $\sim \mathrm{N} 143^{\circ}$ along section $\mathrm{D}$. At the southern termination of the massif the HT lineation becomes oblique to the general direction of the belt and strikes $N 120^{\circ}, 25^{\circ} \mathrm{E}$ along section A (Fisherian average, $k=78.1, \alpha_{95}=3.5^{\circ}, 23 \mathrm{da}-$ ta). The LT lineations have statistically different orien- tations [McFadden and Lowes, 1981] and strike N97 $35^{\circ} \mathrm{E}$ at site $\mathrm{A1}$ (Fisherian average, $k=56.8, \alpha_{95}=4.8^{\circ}$, 17 data) and $\mathrm{N} 91^{\circ}, 31^{\circ} \mathrm{E}$ at site $\mathrm{A} 2$ (Fisherian average, $k=131, \alpha_{95}=4^{\circ}, 11$ data) (Figure 9 ). The lineation at site $\mathrm{DCS} 1$, visible in quartz ribbons, strikes $\mathrm{N} 99^{\circ}, 30^{\circ} \mathrm{E}$ on average.

\section{Ductile Shear Criteria}

Along sections $\mathrm{B}$ and $\mathrm{C}$, all shear criteria indicate a left-lateral sense of shear independent of the dip direction of the schistosity (Figures $5 c$ and $5 d$ ) [Leloup, 1991]. Along section A, consistent shear criteria such as asymmetric tails on deformed feldspar porphyroclasts and $\mathrm{C}$ or C' shear planes [Berthé et al., 1979a,b], observed in vertical sections parallel to the HT lineation, indicate a top to the southeast shear sense (Figure $5 f$ ) and thus a normal/left-lateral shearing (average lineation pitch $\sim 48^{\circ} \mathrm{E}$ ). In contrast, at the eastern extremity of this section, asymmetric tails on deformed feldspar porphyroclasts and shear planes (observed at site A2) in vertical sections parallel to the LT lineation indicate a top to the east shear sense (Figure $5 h$ ) and thus a normal/right lateral shearing (average lineation pitch $\sim 70^{\circ} \mathrm{S}$ ). At site DCS1, many shear planes display a sigmoidal schistosity whose orientation and shape indicate a top to the west sense of shear (i.e., a reverse shear sense).

\section{Shear Criteria on Brittle Structures}

The late chlorite slickensides observed along section $B$ are nearly downdip (pitches vary between $70^{\circ} \mathrm{S}$ and $70^{\circ} \mathrm{N}$ ) on rather steep schistosity planes (Figure $6 c$ ) and 

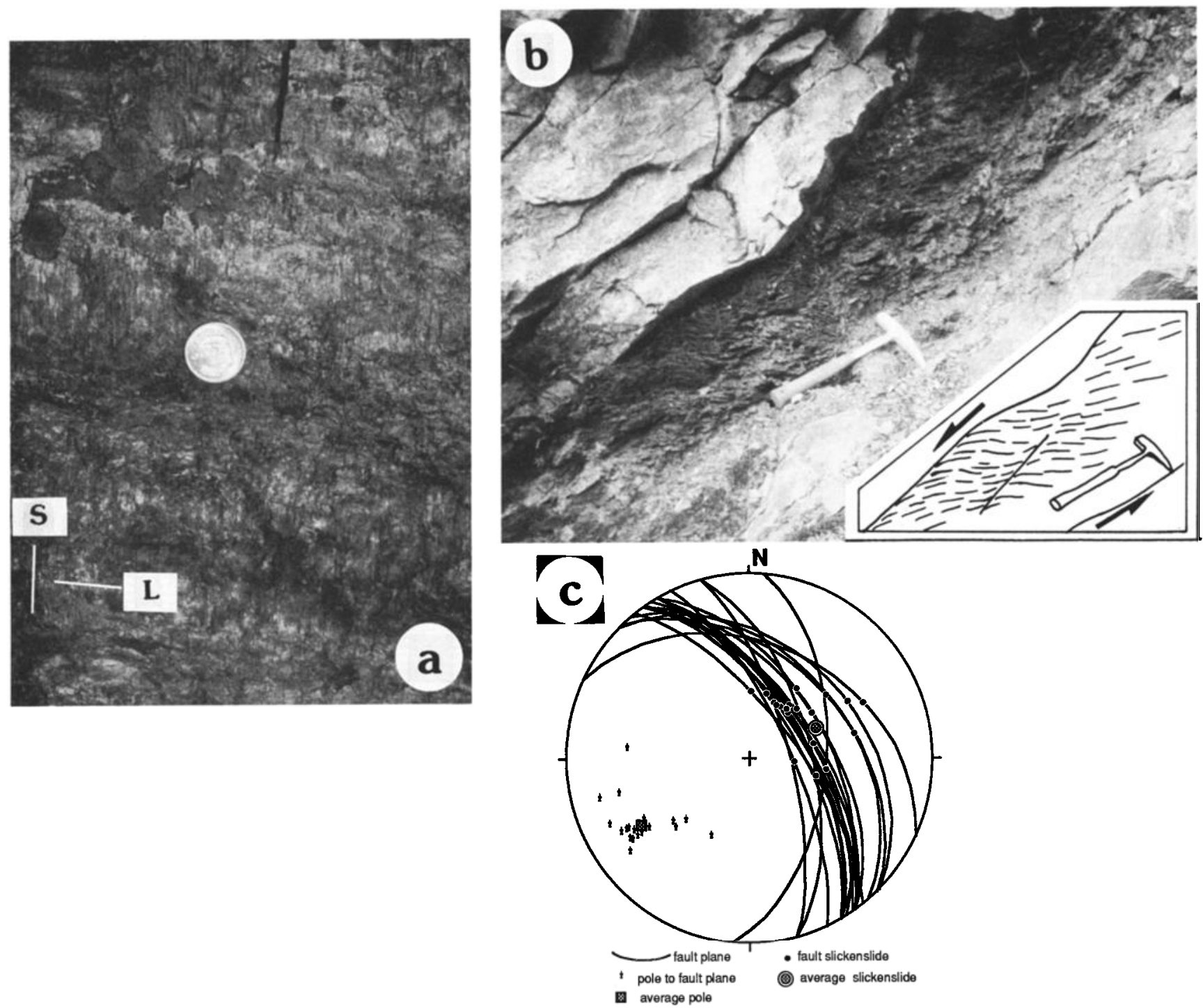

Fig. 6. Late retrograde structures (LT) along section B. (a) Late LT chlorite slickensides (S) with asymmetric crystallizations indicating a normal sense of shear superimposed on steeply dipping schistosity plane bearing HT lineation (L). Schistosity is $\mathrm{N} 148^{\circ}, 62^{\circ} \mathrm{NE}$, HT lineation pitch $25^{\circ}$ to the north, LT slickenslides pitch $80^{\circ}$ to the north. (b) Chlorite fault gouge between gneiss slabs, view toward the south. The shape of the cleavage in the gouge indicate a normal sense of movement. (c) Projection of LT chlorite slickensides along section B. Schmidt diagram, lower hemisphere projection.

show asymmetric crystallizations that indicate a normal sense of shear (Figure 6a). Locally, the sigmoidal shape of the cleavage in chlorite gouge indicates a normal sense of movement (Figure 6b). In several other places along the eastern flank of Diancang Shan we observed massive chlorite pods, often associated with cataclasites, that are clearly related to active normal faulting.

\section{Geothermometry, Geobarometry, and P-T}

Path Analysis From Zoned Garnets

The rocks of the Diancang Shan are predominantly quartzo-feldspathic orthogneisses and paragneisses and amphibolites, with rare pelites. A single staurolitegrade pelitic schists, sample DC-3, from the southwestern side of the Diancang Shan (Figure 8) does, however, contain matrix and inclusion assemblages that allow the P-T history of the sample to be inferred. The shistosity in DC-3 is predominantly defined by strongly foliated muscovite-rich segregations ("muscovite fish") intercalated with more granular biotite-rich layers (Figure $10 a$ ). The matrix assemblage within both regions is quartz + plagioclase + muscovite + biotite + staurolite + garnet + ilmenite + apatite + tourmaline, although garnet porphyroblasts are rare, with a density of less than one per typical thin section area. Chlorite is also relatively rare and is found as inclusions in garnet and also as an apparently relict phase rimming some of the euhedral garnet crystal faces (see below) (Figure 10b). Two generations of compositionally similar $(\mathrm{Fe} / \mathrm{Fe}+\mathrm{Mg}=0.84$ to 0.86$)$, but texturally distinct (euhedral versus anhedral), staurolite porphyroblasts are observed and are abundant within the muscoviterich areas (Figure 10a) and also found within the more granular biotite-rich zones. Muscovite is found replac- 


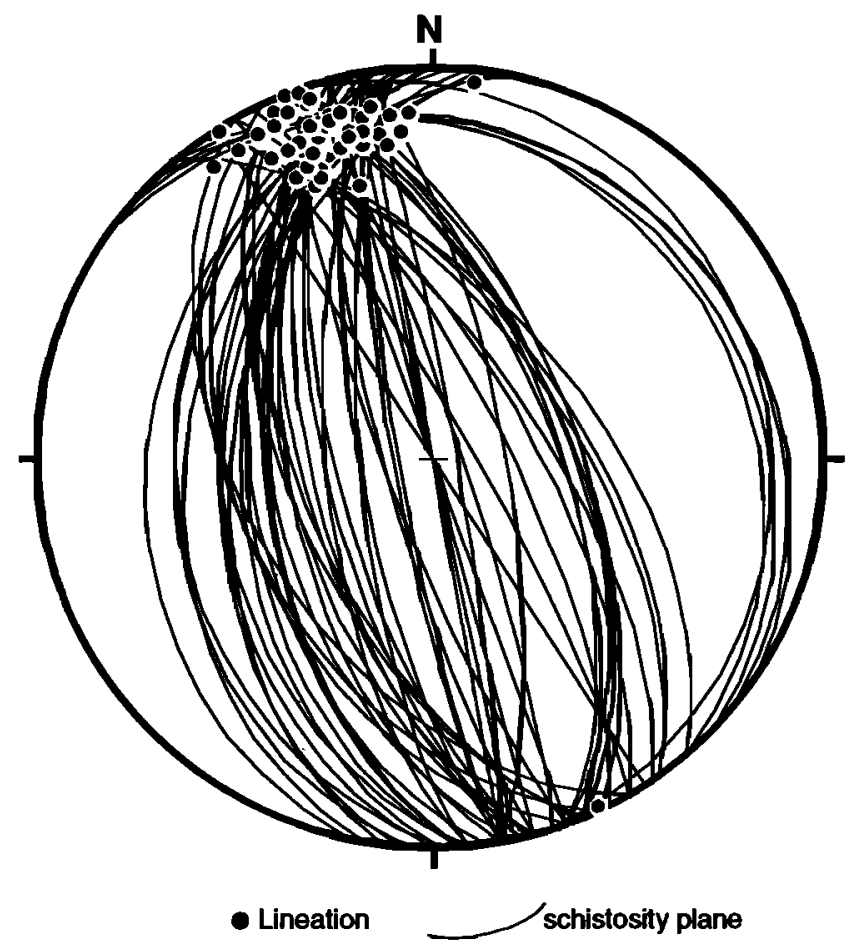

Fig. 7. HT schistosity and lineation attitude along sections $B$ and C. Schmidt diagram, lower hemisphere projection.

ing staurolite within the muscovite-rich regions of the sample. Both staurolite and garnet porphyroblasts contain inclusions whose spatial distribution is largely random; there is no evidence of sinusodial inclusion trails in either phase, and linear inclusions trails are poorly developed. Where linear inclusion arrays (consisting predominantly of ilmenite and quartz) do exist within the staurolites from the muscovite-rich regions, they are at an angle to the foliation, indicating reorientation of the porphyroblasts subsequent to growth. The inclusion assemblage within the garnets consists of chlorite, staurolite, plagioclase, quartz, ilmenite, and apatite. They are not, however, randomly distributed. Staurolite inclusions are observed concentrated within $1 \mathrm{~mm}$ of the garnet rim and are absent from the garnet cores. Biotite is not found as an inclusion in garnet but is found along with staurolite replacing garnet (Figure 10c) The mineralogy to the rim region of the garnet porphyroblasts (within $1 \mathrm{~mm}$ of the rim) suggests that the ferromagnesian assemblage present during growth of this region was garnet-chlorite-staurolite. The absence of staurolite within the garnet core is most likely an indication that chlorite was the only other ferromagnesian phase present during initial growth of the garnet. Garnet growth was terminated by the reaction

$$
\begin{array}{r}
\text { garnet }+ \text { chlorite }+ \text { muscovite }=\text { staurolite } \\
+ \text { biotite }+ \text { quartz }+\mathrm{H}_{2} \mathrm{O}
\end{array}
$$

in which garnet is consumed. This is consistent with the resorption textures along portions of the garnet rims. Two geothermobarometers have been employed to estimate the P-T conditions for DC-3: the garnet-biotite geothermometer (Ferry and Spear [1978], with modifications by Hodges and Spear [1982]) and the garnetplagioclase-muscovite-biotite geobarometer (Ghent and
Stout [1981], with modifications by Hodges and Crowley [1985]). Geothermobarometry yields a P-T estimate of approximately $570^{\circ} \mathrm{C}$ and $5.0 \mathrm{kbar}$ from the rim compositions of matrix minerals. Unfortunately, the absence of biotite inclusions within the garnet precludes use of this type of analysis for P-T path reconstruction. A partial P-T history for sample DC-3 can be reconstructed using the compositional zoning within the garnets coupled with the methods described by Spear and Selverstone [1983]. The assumptions used in modeling the P-T history of DC-3 are described below, and the compositional data were modeled using the computer programs of Spear et al. [1991].

Maps of the chemical zonation of a garnet from DC-3 are displayed in Figure 11 and the garnet zoning profiles used for the P-T calculations are given in Figure 12a12d. Zonation profiles within the almandine-rich garnet infer a fairly simple growth history. The contours for the various garnet components are concentric and truncated by areas of resorption, suggesting a single episode of growth followed by a reaction in which garnet is consumed. Grossular $\left(\mathrm{Ca}_{3} \mathrm{Al}_{2} \mathrm{Si}_{3} \mathrm{O}_{8}\right)$ and spessartine $\left(\mathrm{Mn}_{3} \mathrm{Al}_{2} \mathrm{Si}_{3} \mathrm{O}_{8}\right)$ concentrations are both relatively high and flat in the core of the garnet. The concentrations of both components dips fairly sharply near the rim where the staurolite inclusions are found. Similarly, the concentrations of almandine $\left(\mathrm{Fe}_{3} \mathrm{Al}_{2} \mathrm{Si}_{3} \mathrm{O}_{8}\right)$ and pyrope $\left(\mathrm{Mg}_{3} \mathrm{Al}_{2} \mathrm{Si}_{3} \mathrm{O}_{8}\right)$ are also relatively constant throughout the core of the garnet but rise in the rim region. The $\mathrm{Fe} / \mathrm{Fe}+\mathrm{Mg}$ ratio drops monotonically across the porphyroblast. These zoning patterns are consistent with the reaction history inferred above.

Two factors worthy of additional consideration are (1) the effects of garnet resorption on P-T path calculation and (2) the weak zonation within the garnet core relative to that observed in the rim. Staurolite growth at the expense of garnet can obscure the primary growth zoning and make retrieval of the P-T path impossible. In this particular garnet, such resorption is manifest. However, the pattern of resorption with respect to the positions of the compositional contours suggests that the euhedral faces of the garnet have not been affected by this process and can be employed in modeling the P-T path of this sample. The weak zonation within the garnet core is consistent with initial garnet growth in a high variance assemblage in which garnet composition is largely controlled by the composition rock, rather than by constraints imposed by the phase assemblage. Subsequent zoning is the result of a decrease in variance due to the appearance of additional phases. The P-T path for the rim region of the garnet can be modeled assuming that one of three following phase assemblage existed during its growth: (1) quartz + muscovite + plagioclase + chlorite + staurolite + garnet $+\mathrm{H}_{2} \mathrm{O}$, (2) quartz + muscovite + plagioclase + chlorite + biotite + garnet $+\mathrm{H}_{2} \mathrm{O}$, and (3) quartz + muscovite + plagioclase + biotite + staurolite + garnet $+\mathrm{H}_{2} \mathrm{O}$. The reactions describing assemblage 1 (staurolite + chlorite + garnet) and assemblage 2 (chlorite + biotite + garnet) both produce garnet. Based upon the petrographic observations outlined above and the absence of biotite inclusions in the garnet, we believe that assemblage 1 is the more likely assemblage to have been present during growth of the garnet rim. Assemblage 3 is the assem- 


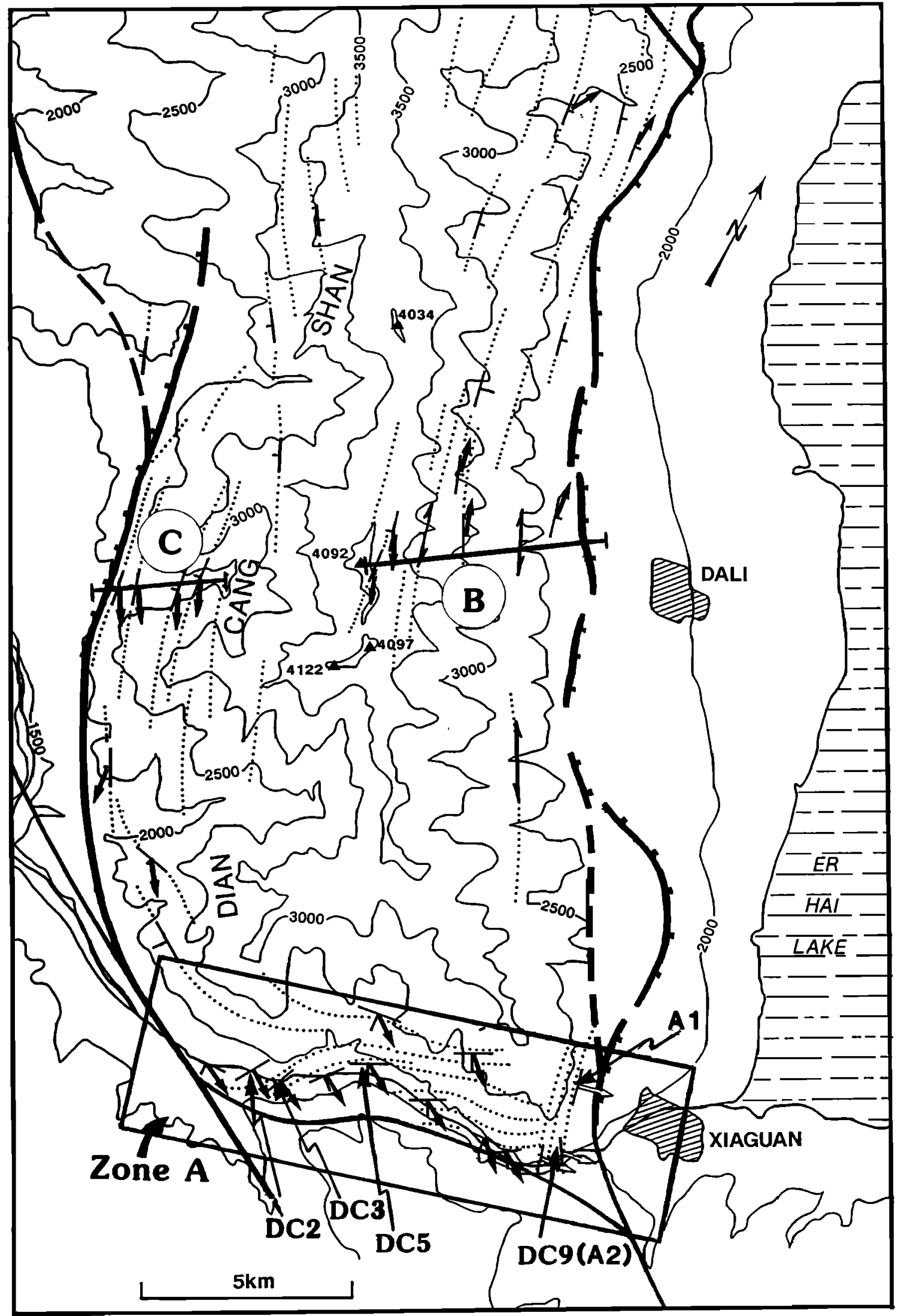

Fig. 8. Structural map of the southern termination of the Diancang Shan (frame on Figure 2) and location of samples DC2, DC3, DC5, and DC9c. Structures drawn from field observations and SPOT images, topography from Chinese $1 / 100,000$ maps. Strike and dip symbols indicate direction and dip of the schistosity. Dashed lines correspond to extrapolation of the schistosity direction between the measured points. Arrows indicate the lineation and point toward the shear direction (hanging wall movement). Dark arrows corresponds to HT structures, open ones to LT structures. 


\begin{tabular}{|c|c|c|c|}
\hline 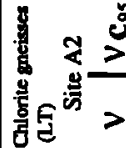 & & & $\frac{\stackrel{0}{0}}{\stackrel{\Delta}{0}}$ \\
\hline 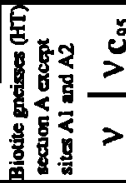 & & $\frac{n}{n}$ & 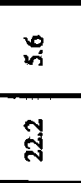 \\
\hline $\begin{array}{l}\nwarrow \\
\alpha\end{array}$ & nn & $\nabla$ & $\stackrel{\infty}{\rightarrow}$ \\
\hline 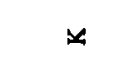 & $\vec{\infty}$ & $\bar{m}$ & $\begin{array}{l}\infty \\
\stackrel{\circ}{\circ}\end{array}$ \\
\hline 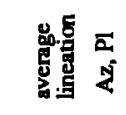 & 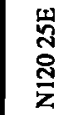 & $\frac{m}{\frac{m}{2}}$ & 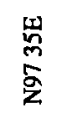 \\
\hline$z$ & $\mathscr{N}$ & $=$ & $\Xi$ \\
\hline (0) $\frac{\text { ․ㅡㄹ }}{\frac{5}{3}}$ & 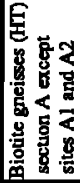 & 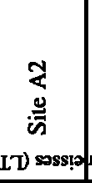 & 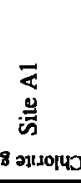 \\
\hline
\end{tabular}

\begin{tabular}{|c|c|c|}
\hline & \\
\hline & & 0 \\
\hline
\end{tabular}

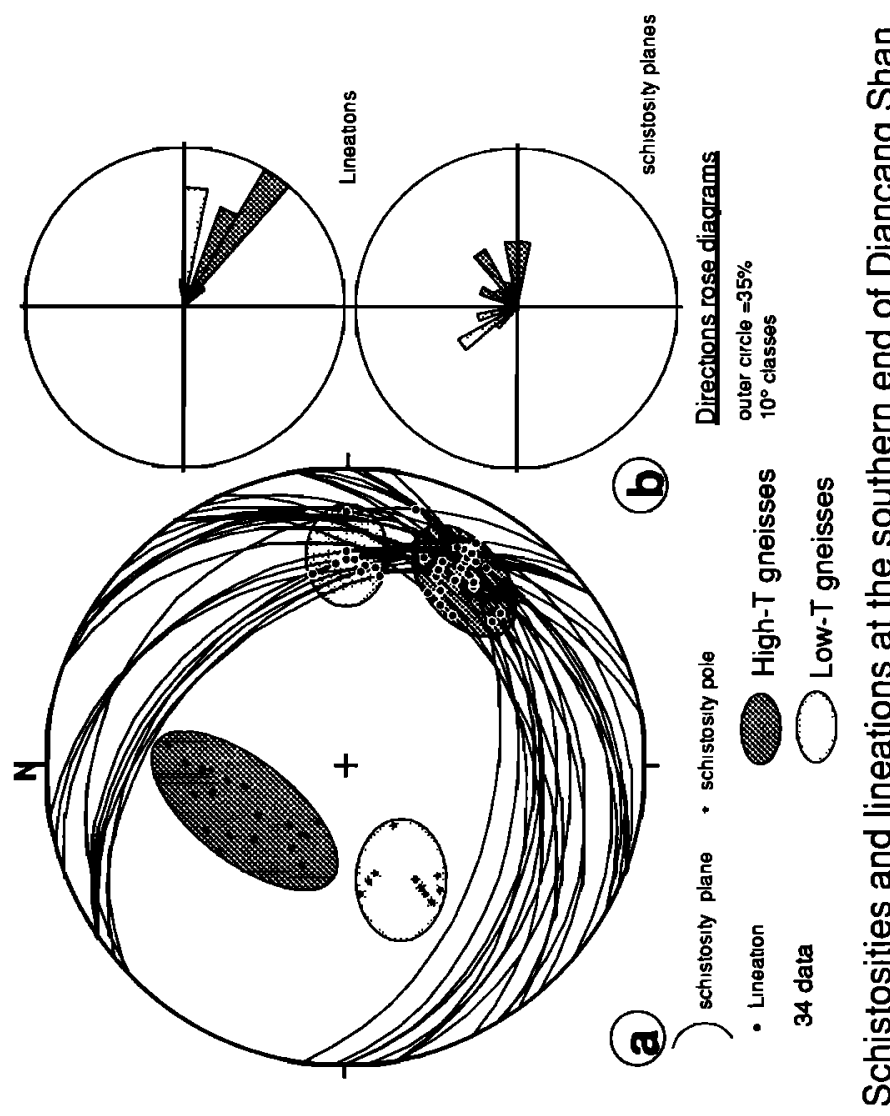

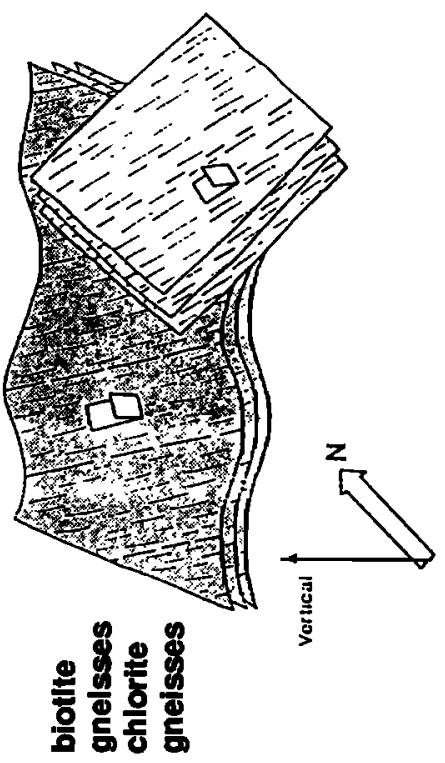

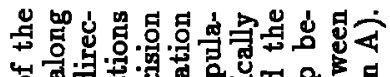
㟧

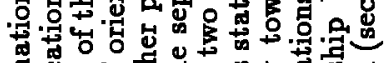
.

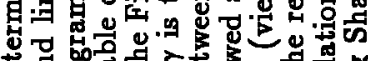
药.

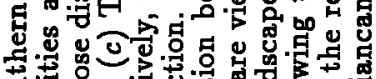

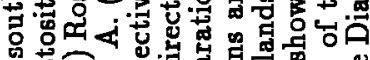

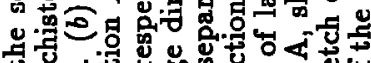

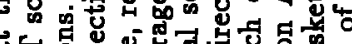

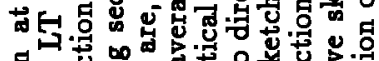

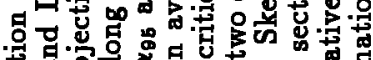
越乐

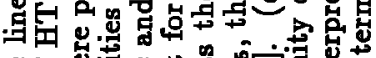

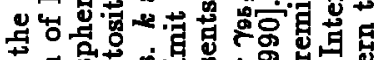

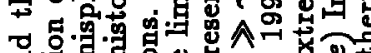

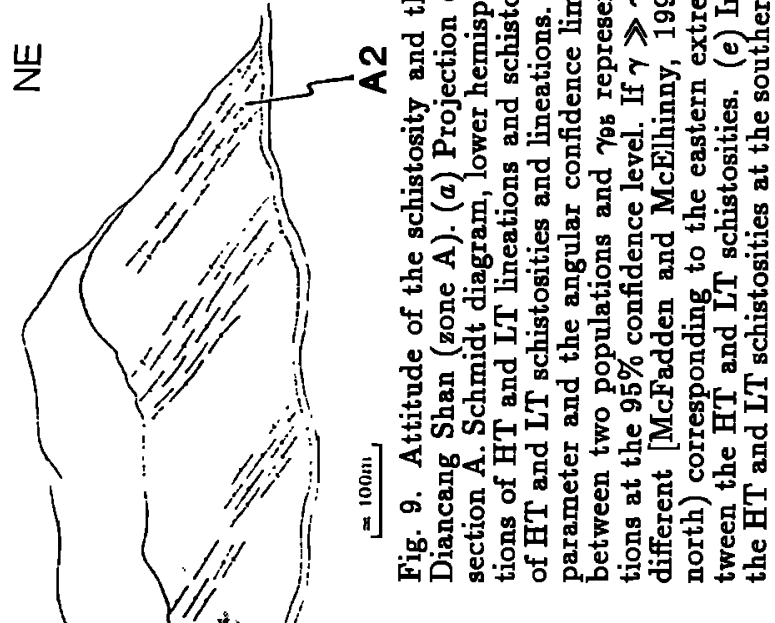

$\sum_{\infty}^{3}$

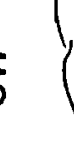

(ृ) 


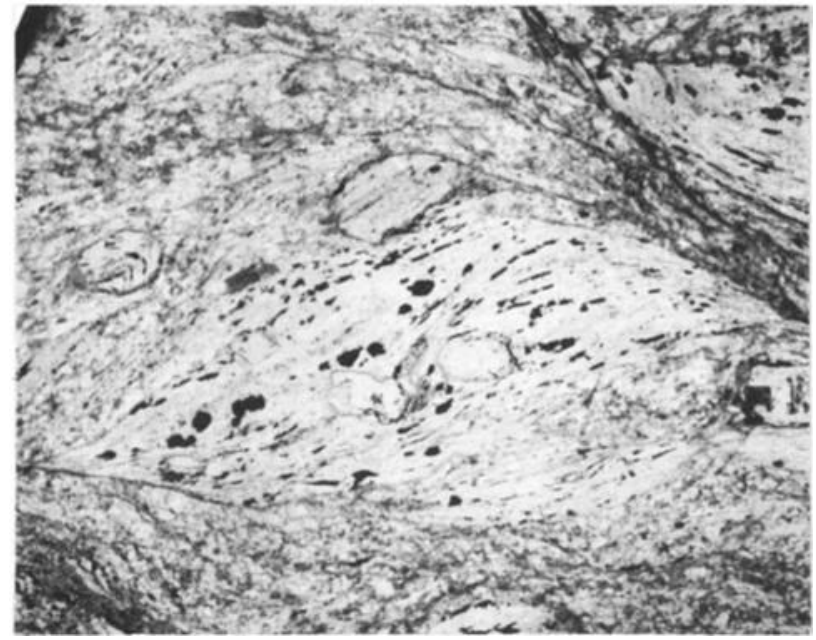

(a)

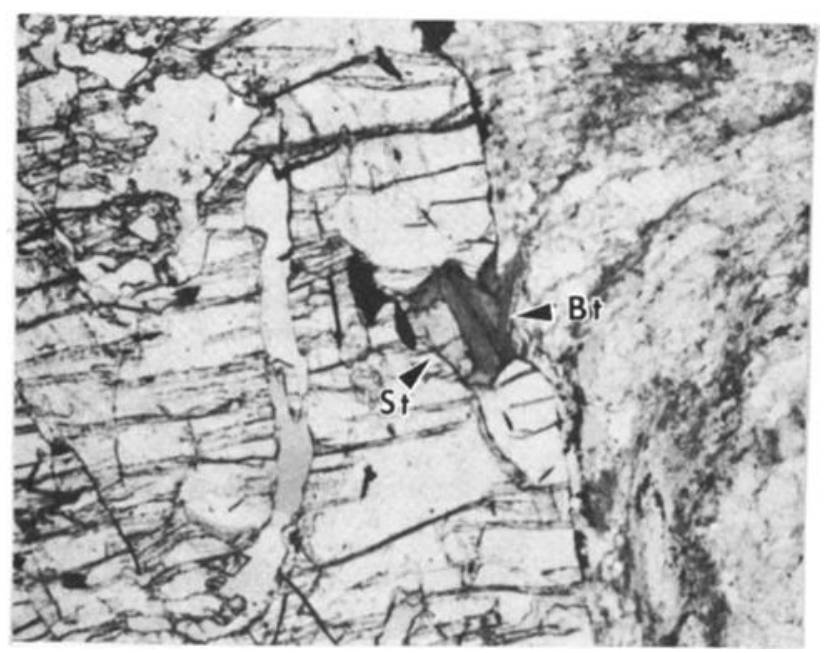

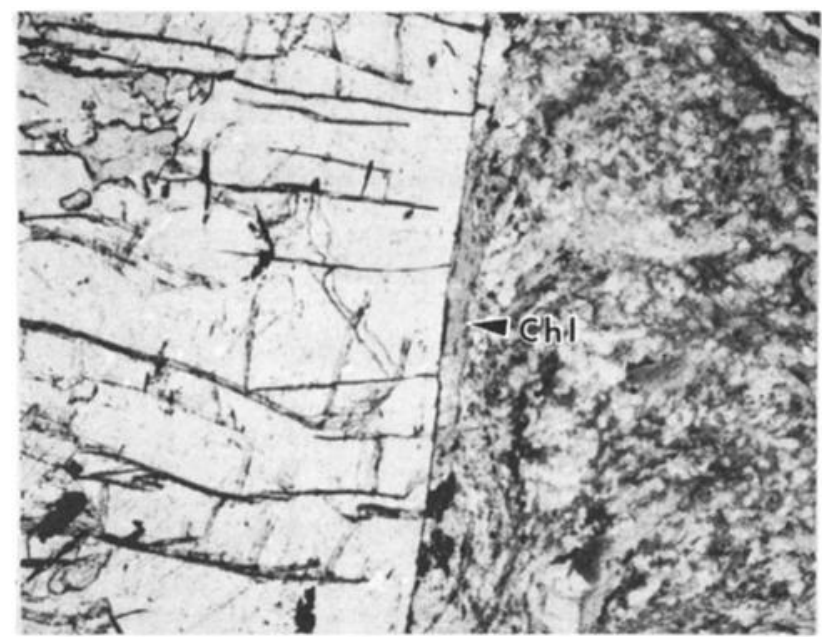

(b)

(c)

Fig. 10. (a) Photomicrograph of a region with sheared "muscovite-fish" containing both euhedral and anhedral staurolites, (b) unaltered edge of garnet porphyroblast with rimming chlorite, the composition of this chlorite was used in the P-T path analysis, (c) staurolite and biotite growing in an embayment in the garnet porphyroblast.

blage found in the sample matrix. However, this reaction among these phases (equation (1)) consumes garnet and is therefore unlikely to have controlled growth of the garnet rim. We will restrict further discussion to the paths obtained from modeling assemblages 1 and 2.

Assemblages 1 and 2 are quadravariant in the system $\mathrm{SiO}_{2}-\mathrm{Al}_{2} \mathrm{O}_{3}-\mathrm{MgO}-\mathrm{FeO}-\mathrm{MnO}-\mathrm{CaO}-\mathrm{Na}_{2} \mathrm{O}-\mathrm{K}_{2} \mathrm{O}-$ $\mathrm{H}_{2} \mathrm{O}$. Calculation of the P-T path requires (1) a starting $\mathrm{P}-\mathrm{T}$ condition, $570^{\circ} \mathrm{C}$ at $5 \mathrm{kbar}$, which was obtained from the matrix mineral compositions plus garnet rim compositions above, and (2) specification of four independent compositional parameters as a function of garnet growth corresponding to the incremental variations in $\mathbf{P}$ and $\mathrm{T}$. The composition of the garnet (three independent components) surrounding plagioclase inclusions and that of the plagioclase inclusions (one independent component) were used as monitors in this calculation. It should be noted that the plagioclase in- clusions within the garnet show very little systematic compositional variation with position (Figure 12a-d). With the exception of one analysis of a plagioclase from a plagioclase-chlorite inclusion $\left(\mathbf{A n}_{26}\right)$, all of the inclusions lie between $A_{28}$ and $A_{2} n_{29.5}$. Spear et al. [1990] have illustrated that in the absence of other Ca-bearing phases, plagioclase composition should vary systematically with the grossular concentration of the garnet. We believe that the minor variation in plagioclase composition observed here is due to the very low abundance of garnet within the rock and the minor impact of garnet growth on the calcium concentration of the matrix.

The modeled P-T paths are shown on the petrogenetic grid of Spear and Cheney [1989] (Figure 13), who have calculated the effect of $\mathrm{MnO}$ and $\mathrm{CaO}$ on the positions of reaction boundaries in the $\mathrm{SiO}_{2}-\mathrm{Al}_{2} \mathrm{O}_{3}-\mathrm{MgO}$ $\mathrm{FeO}-\mathrm{K}_{2} \mathrm{O}-\mathrm{H}_{2} \mathrm{O}$ system (shown as dashed lines corresponding to the mole fraction of spessartine component 

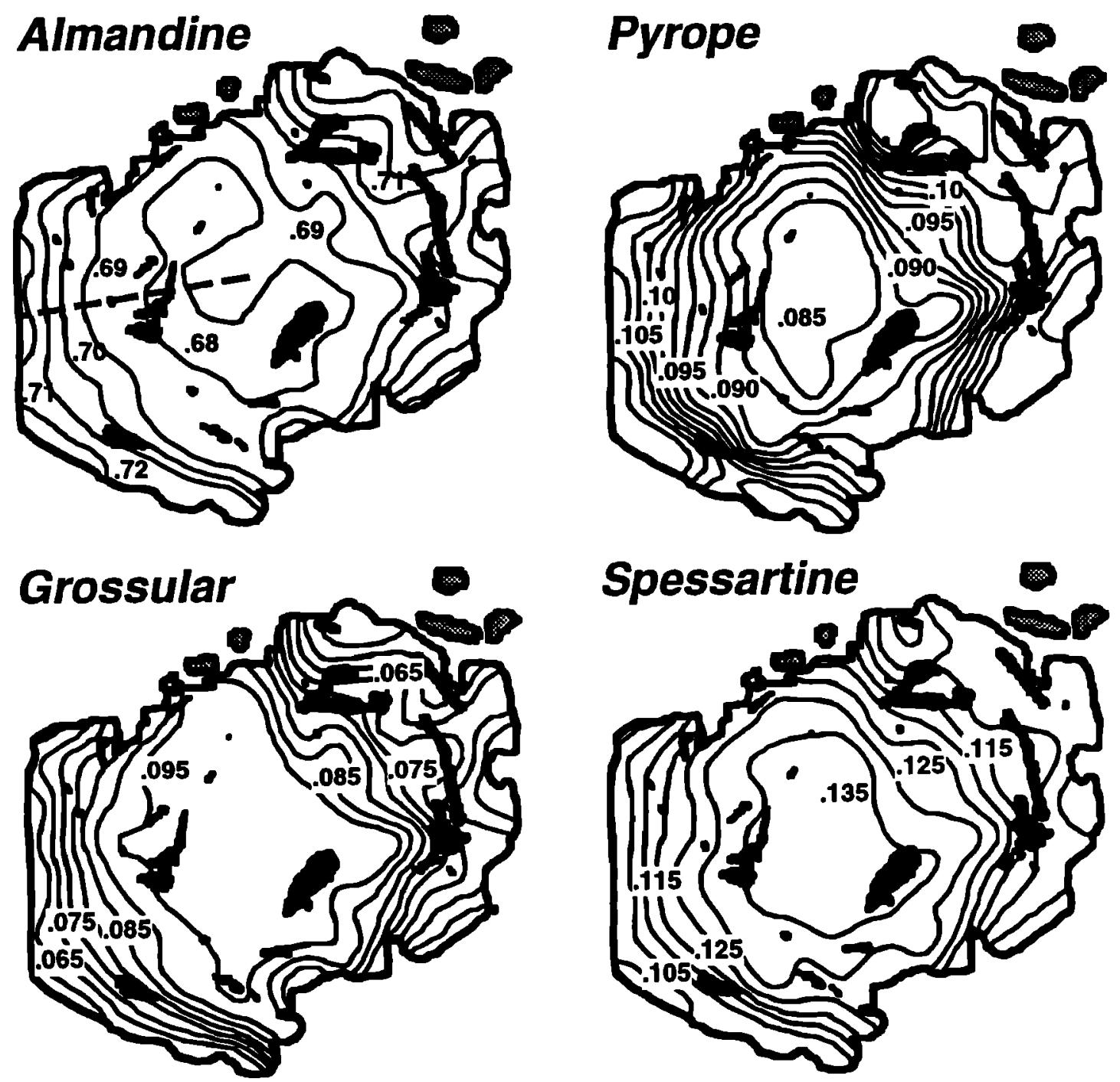

Fig. 11. Compositional zoning in garnet displaying concentric zonation truncated by areas of garnet resorption. The zoning profile in Figure 12 was collected along the trace shown by the dashed line.

in garnet). The garnet in DC-3 contains $\sim 0.10$ mole fraction spessartine and $\sim 0.05$ mole fraction grossular. The P-T path based upon assemblage 1 (staurolite + chlorite + garnet) indicates that the growth of the garnet rim took place during relatively isothermal decompression $\left(\Delta \mathrm{T}^{\text {eore-rim }} \sim 20^{\circ} \mathrm{C}\right)$ which began at $\sim 7 \mathrm{kbar}$ $\left(\Delta \mathrm{P}^{\text {core-rim }} \sim 2 \mathrm{kbar}\right.$ ). Analysis of assemblage 2 (chlorite + biotite + garnet) yields a virtually identical P-T path $\left(\Delta \mathrm{T}^{\text {core-rim }} \sim 20^{\circ} \mathrm{C}, \Delta \mathrm{P}^{\text {core-rim }} \sim 1.7 \mathrm{kbar}\right)$. The results are in excellent agreement with the petrogenetic grid of Spear and Cheney [1989] for the appropriate garnet composition with the endpoint of the path corresponding very well with the location of the reaction chlorite + garnet $=$ staurolite + biotite which terminates garnet growth. It is important to recognize that this path represents only the P-T history of the sample during the growth of the rim area of the garnet. A small portion of garnet growth, represented by the weakly zoned core, preceded this stage of the sample's history and probably took place under conditions of increasing pressure and temperature.

\section{Thermal History of the Gneisses}

To retrieve thermal history information from a $\mathrm{K}$ feldspar age spectrum, we use an extension of the single diffusion domain/activation energy closure theory [Dodson, 1973] that applies to minerals with a discrete distribution of domain sizes or activation energies [Lovera et al., 1989, 1991, 1993; Harrison et al., 1991; Fitz Gerald and Harrison, 1993]. Arrhenius plots and age spectra derived from the thermal degassing of such samples are a mixture of those characterizing the individual diffusion domains. The diffusion parameters (activation energy $E$ and frequency term $D_{o} / \rho^{2}$ ) for each discrete domain are obtained by iterating between fits to the Arrhenius plot and age spectrum. Once the diffusion parameters have been acquired, the thermal history is obtained by repeated forward modeling of the age spectrum. Thermal cycling during step-heating permits assessment of a change in activation energy between domains [Harrison et al., 1991]. Although we observe deviations on the $\log \left(r / r_{0}\right)$ plots that suggest such vari- 

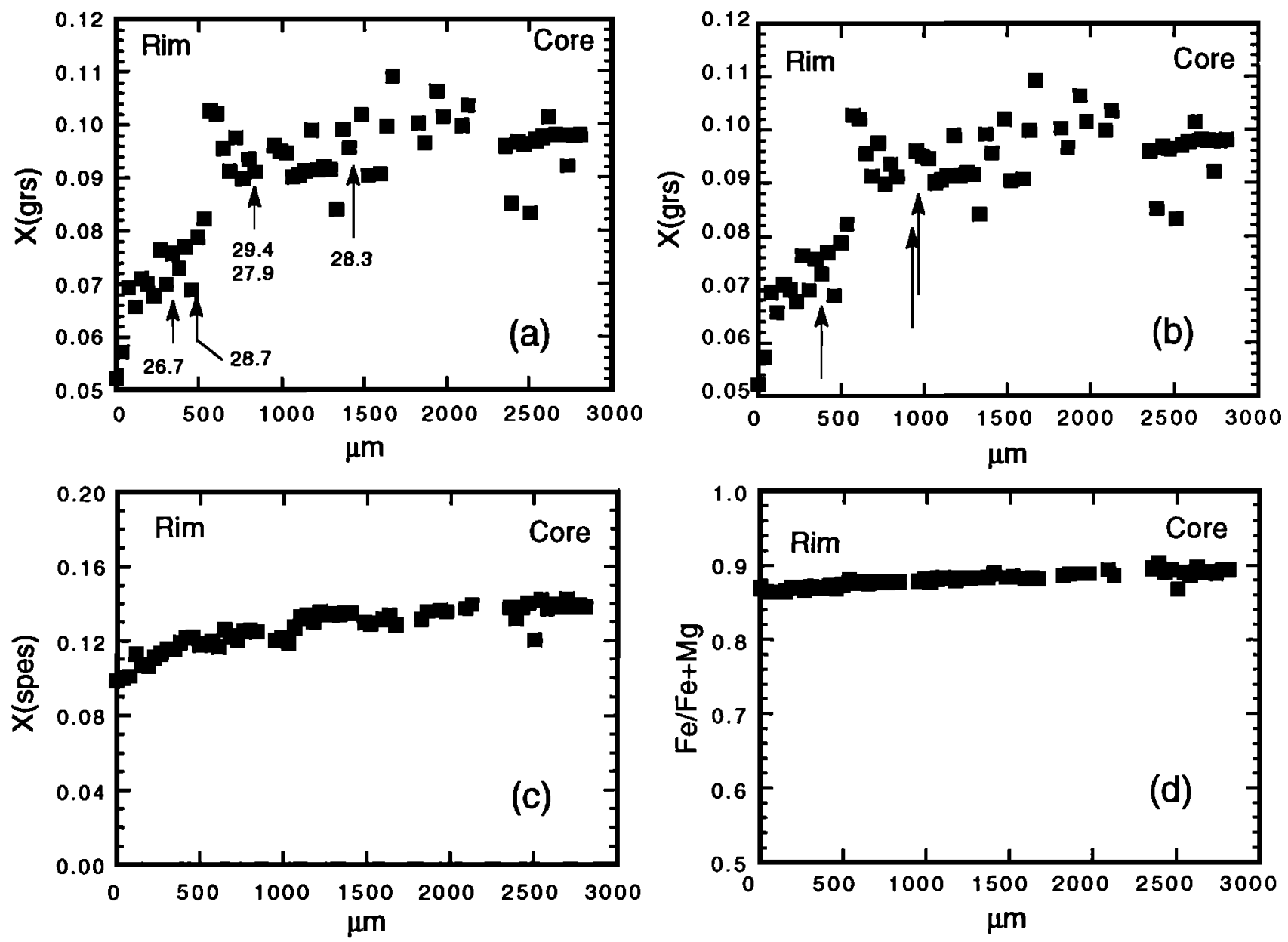

Fig. 12. Compositional zoning in garnet porphyroblast from DC3. (a) Grossular, arrows show positions of plagioclase inclusions correlated with the composition of garnet along this traverse, numbers are mole percent anorthite in plagioclase, (b) grossular, arrows show positions of staurolite inclusions correlated with the composition of garnet along this traverse, (c) spessartine, and (d) $\mathrm{Fe} / \mathrm{Fe}+\mathrm{Mg}$ atomic ratio.

ations, we are hesitant in interpreting thermal histories in this way because of potential artifacts in the Arrhenius data close to the melting point of feldspars [e.g., Richet and Fiquet, 1991]. However, the results obtained assuming a single $-E$ and varying domain sizes [e.g., Lovera et al., 1989] yield the same general form of thermal history compared to those using the multi- $E$ assumption. Thermal histories calculated in these two different ways differ only in a temperature offset of the slow cooling segment, the magnitude of which depends on the apparent contrast in $\boldsymbol{E}$. We illustrate the thermal histories for each sample arising from both assumptions (Figures 15-20) but use only the results for single-E in the subsequent discussion. Model sensitivity to input parameters is described in detail elsewhere [Lovera et al., 1991, 1992, 1993; Harrison et al., 1991; Richter et al., 1991].

Three K-feldspars were analyzed from zone A (DC2a, DC5, DC9c, Figure 8) and three from section B (DC10c, DC16, DC28, Figure 4). All age spectra are characterized by ages of about $5 \mathrm{Ma}$, between 2 and $\sim 20 \%{ }^{39} \mathrm{Ar}$ release, which then rise smoothly to ages of about 20 Ma for DC9c, $17 \mathrm{Ma}$ for DC16 and $10 \mathrm{Ma}$ for the other samples (Figure 14). We analyzed also three biotites, two white micas and one amphibole. We illustrate our methodology by first describing the details of our modeling using results for DC9c K-feldspar.

DC9c. DC9c K-feldspar age spectrum, shown in Figure $15 a$, is characterized by an age of $\sim 5 \mathrm{Ma}$ over the first $20 \%$ of gas release followed by ages that increase up to a maximum of about $20 \mathrm{Ma}$. ${ }^{39} \mathrm{Ar}$ diffusivities were calculated (assuming a plane slab geometry) and plotted against the reciprocal heating temperature yielding the Arrhenius plot shown in Figure 15b. Because of the effects of differing diffusion domain sizes and/or activation energies and the cyclic nature of the laboratory heating schedule (inset to Figure 15b) needed to bring out the activation parameters, the Arrhenius plot is not an effective way of displaying the domain structure. The diffusion data are shown in Figure $15 c$ plotted as $\log \left(r / r_{o}\right)$ versus Cumulative \% ${ }^{39} \mathrm{Ar}$ released [see Love$r a$ et al., 1991]. As mentioned earlier, we have fit these results using both a model that assumes a common $E$ among domains and one in which $E$ is varied to fit the small deviations arising from temperature cycling.

The single- $E$ model was obtained using an automated fitting routine whereas the multi- $E$ result was acquired manually explaining the generally better over- 


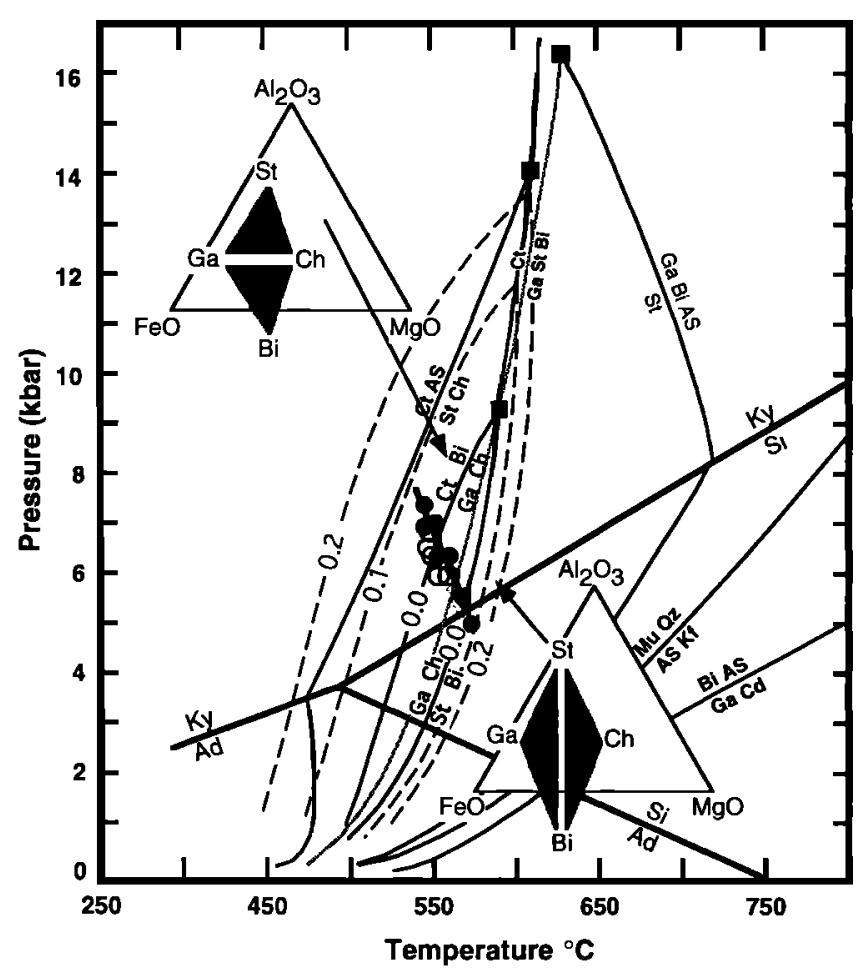

Fig. 13. P-T path calculated from garnet zoning in DC-3 for assemblage 1 (garnet + chlorite + staurolite, shown as solid symbols) and for assemblage 2 (garnet + biotite + chlorite, shown as open symbols) shown on the petrogenetic of Spear and Cheney [1989]. The dashed lines show the effect of $\mathrm{MnO}$ addition to garnet on the stability of garnet-chlorite assemblages and are contoured in mole fraction spessartine component in the garnet.

all fit of the single- $E$ results. The FORTRAN codes and documentation are available through anonymous $\mathrm{ftp}$ to radon.ess.ucla.edu (128.97.31.46) in the directory pub/auto-prog. The automatic routine calculates the Arrhenius and $\log \left(r / r_{0}\right)$ plots from the ${ }^{39} \mathrm{Ar}$ data and compares these to the synthetic plots obtained using the optimum diffusion parameters calculated by a variational-iterative method. The difference of this approach from our previous routines is that it eliminates operator subjectivity during the process of finding the optimum parameters by eliminating the manual modelling. The activation energy is calculated applying a heavily weighted leastsquares to the initial data in the step-heating experiment. Starting by calculating $E$ from the first three points, it iteratively calculates $E$ by adding subsequent points one by one until the apparent $E$ begins to decrease (marking the point where the linear array bends toward the largest domains) and then chooses this value as the effective sample $E$. After calculating $E$, the program uses a variational-iterative method to find the domain distribution (number of domains, sizes, and concentrations) which best fits the laboratory derived data. The $E$ and domain distribution parameters obtained by this method (and given in the inset of Figure 15c) reproduce most of the features of the $\log \left(r / r_{0}\right)$ plot. The multi-E fit to the data assumes the presence of six domains with the $E$ and $D_{o} / \rho^{2}$ values also given in the inset of Figure $15 c$. The peaks at 30,55 , and $85 \%{ }^{39} \mathrm{Ar}$ release are a consequence of apparent multiple activation energies together with cycled heating steps [Harrison et al., 1991] and are well duplicated using this choice of parameters (Figure 15c). Although the single- $E(46.5 \mathrm{kcal} / \mathrm{mol})$ model does not reproduce these features, it does provide an overall excellent fit with a minimum of assumptions.

Once the domain distribution parameters are determined, the thermal history is then obtained by recursively adjusting the input cooling history until an acceptable fit to the age spectrum (Figure 15a) is achieved. The single $-E$ thermal history (Figure $15 d$ ) is characterized by initial cooling at a rate of $\sim 50^{\circ} \mathrm{C} / \mathrm{m}$.y. between 25 and $21 \mathrm{Ma}$ followed by an essentially isothermal interval at $\sim 285^{\circ} \mathrm{C}$ that lasted until $5 \mathrm{Ma}$ when cooling at a rate of $\sim 80^{\circ} \mathrm{C} / \mathrm{m}$.y. began abruptly. The model is not sensitive in the region of the initial cooling (i.e., the $50^{\circ} \mathrm{C} / \mathrm{m}$.y. portion) and the actual value could be substantially different from that chosen. In contrast, the cooling rate subsequent to $\sim 21 \mathrm{Ma}$ is well constrained and essentially independent of assumptions regarding $E$. Although it is necessary for computational reasons to begin and end the model thermal history at temperatures outside the true closure interval of the sample, ages older or younger than those observed on the age spectrum are not constrained at all. Those portions of the thermal history used in the calculations that lie outside the observed age spectrum are indicated by dashed extensions of the thermal history curves (Figures 15d-20d). An age spectrum was also obtained from the coexisting white mica (Figure 15a). Because this phase is unstable during vacuum heating, we cannot perform a similar diffusion analysis on these results as was done with the K-feldspar. However, it is generally believed that the closure temperature $\left(T_{c}\right)$ of this phase is approximately $350-400^{\circ} \mathrm{C}$ [e.g., Wagner et al., 1977; McDougall and Harrison, 1988]. The spectrum yields an age of $\sim 22 \mathrm{Ma}$ over the last $85 \%$ of gas release. This age and closure temperature are consistent with the K-feldspar thermal history (Figure 15d).

DC2a. The K-feldspar age spectrum (Figure 16a) gives an age of $4.3 \mathrm{Ma}$ over the first $35 \%{ }^{39} \mathrm{Ar}$ release, then rises to ages as old as $10 \mathrm{Ma}$. The modeled thermal history begins with cooling progressing at $180^{\circ} \mathrm{C} / \mathrm{m}$.y. until a temperature of $310^{\circ} \mathrm{C}$ is reached at $10.3 \mathrm{Ma}$. Cooling is then very slow $\left(1^{\circ} \mathrm{C} / \mathrm{m} . \mathrm{y}\right.$. $)$ until $5 \mathrm{Ma}$ when cooling at $100^{\circ} \mathrm{C} / \mathrm{m}$.y. causes final argon closure (Figure $16 d$ ). The coexisting biotite and white mica yield plateau ages of $9.5 \pm 0.5$ and $15.4 \pm 0.8 \mathrm{Ma}$, respectively (Figure 16a), which are consistent (assuming a $T_{c}$ for biotite of $300 \pm 50^{\circ} \mathrm{C}$ ) with the thermal history generated by the K-feldspar alone (Figure 16d).

DC5. The K-feldspar results (Figure 17a-d) show an age spectrum that rises from $4.5 \mathrm{Ma}$ over the first $35 \%$ of gas release to ages as old as $10 \mathrm{Ma}$. It proved diffcult to obtain a good model fit for this sample, possibly due to a nonatmospheric trapped argon component released between 65 and $85 \%{ }^{39} \mathrm{Ar}$ release. Otherwise, this spectrum (and thus thermal history) shares most detail$\mathrm{s}$ of the other samples. The coexisting biotite yields a plateau age of $6.4 \pm 0.3 \mathrm{Ma}$ (Figure 17a), consistent with the thermal history deduced from the K-feldspar (Figure $17 \mathrm{~d})$.

$D C 10 c$. Initial ages of $4.5 \mathrm{Ma}$ also characterize this K-feldspar age spectrum (Figure 18a) but are followed 


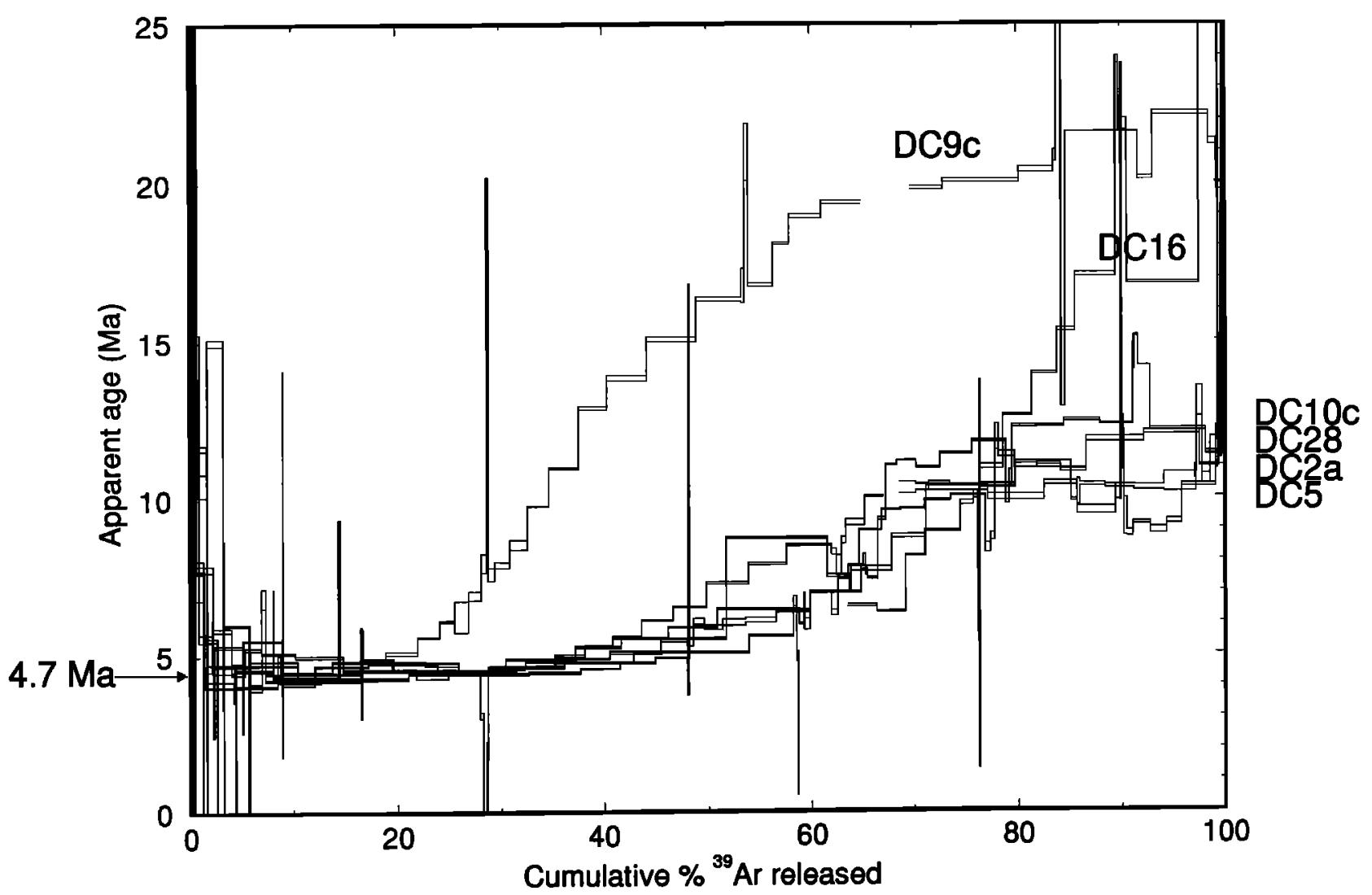

Fig. 14. K-feldspar age spectra for samples DC2a, DC5, DC9c, DC10c, DC16, and DC28.

by an erratic pattern rising to a small plateau at $12 \mathrm{Ma}$ between 78 and $96 \%{ }^{39} \mathrm{Ar}$ released. The modeled cooling history (Figure $18 d$ ) begins cooling at $60^{\circ} \mathrm{C} / \mathrm{m} . \mathrm{y}$. until $10 \mathrm{Ma}\left(290^{\circ} \mathrm{C}\right)$, then remains nearly isothermal (cooling at $\sim 1^{\circ} \mathrm{C} / \mathrm{m} . \mathrm{y}$.) until $4 \mathrm{Ma}$, and abruptly begins to cool rapidly $\left(\sim 300^{\circ} \mathrm{C} / \mathrm{m} . \mathrm{y}\right.$.). The coexisting biotite yields a plateau age of $7.3 \pm 0.1 \mathrm{Ma}$ (Figure 18a). A hornblende age spectrum from a nearby sample (DC10a) was also obtained (Figure 18a). The average age of the last six heating steps is $22.1 \pm 2.2 \mathrm{Ma}$. Hornblende closure temperature is estimated at $500 \pm 50^{\circ} \mathrm{C}$ [McDougall and Harrison, 1988]. The low initial ages may reflect argon loss during the period at elevated temperature.

DC16. The K-feldspar age spectrum begins with a plateau age of $4.7 \mathrm{Ma}$ until $55 \%$ of gas release and then rises steeply to ages close to $17 \mathrm{Ma}$ (Figure 19a). The modeled history (Figure 19d) begins with cooling at $100^{\circ} \mathrm{C} / \mathrm{m}$.y. until $17 \mathrm{Ma}\left(330^{\circ} \mathrm{C}\right)$, then remains nearly isothermal (cooling at $\sim 1^{\circ} \mathrm{C} / \mathrm{m}$.y.) until 4.3 Ma, and abruptly begins to cool rapidly $\left(200^{\circ} \mathrm{C} / \mathrm{m}\right.$.y.).

DC28. As with all other $\mathrm{K}$-feldspars, this age spectrum (Figure 20a) yields an initial plateau close to 4.5 $\mathrm{Ma}$ (between 10 and $37 \%{ }^{39} \mathrm{Ar}$ release). Thereupon, ages rise to a small plateau at 11-12 Ma over the last $25 \%$ of ${ }^{39} \mathrm{Ar}$ release. The modeled cooling history (Figure $20 d$ ) begins at a rate of $80^{\circ} \mathrm{C} / \mathrm{m}$.y. reaching a temperature of $315^{\circ} \mathrm{C}$ by $11.6 \mathrm{Ma}$. The cooling rate between 11.6 and $10.2 \mathrm{Ma}$ is $30^{\circ} \mathrm{C} / \mathrm{m}$.y. followed by a nearly constant temperature (cooling is $\sim 0.5^{\circ} \mathrm{C} / \mathrm{m}$.y., starting at $270^{\circ} \mathrm{C}$ ) until $4.1 \mathrm{Ma}$ when very rapid cooling begins $\left(550^{\circ} \mathrm{C} / \mathrm{m} . \mathrm{y}.\right)$.

\section{Discussion}

\section{Structural Interpretation}

HT structures. The gneisses in the core of the Diancang Shan display spectacular characteristics of large ductile strains, such as mylonites and sheath folds. Schistosity and lineation trends, various shear criteria from microscopic to large scale, are consistent with a left-lateral shear sense, indicating a deformation regime close to simple shear. As in the Ailao Shan [Tapponnier et al., 1990], the core of the Diancang Shan seems to be a 10- to $15-\mathrm{km}$-wide shear zone in which leftlateral, progressive shearing occurred. As indicated by the high strain in the rocks, progressive shearing occurs subparallel to the presently observed schistosity in a direction close to the stretching lineation [Escher and Watterson, 1974; Mattauer, 1975]. The hypothesis that the Diancang Shan could be a large fold of preexisting mylonites is dismissed by the fact that left-lateral shear criteria are found everywhere, no matter what the dip direction of the schistosity is [Leloup, 1991]. In the Diancang Shan, the left-lateral deformation is believed to have been active until after $24.4 \mathrm{Ma}$ as monazite U$\mathrm{Pb}$ ages in deformed granite pods give this age [Liu et al., 1992]. In the Ailao Shan, dating of similarly deformed anatectic pods yield an age of $23 \mathrm{Ma}$ [Schärer et al., 1990]. The fact that the Diancang Shan lies in the prolongation of the Ailao Shan (Figure 1) and the similarities in their structure and timing leads us to conclude that the Diancang Shan and the Ailao Shan massifs were parts of the same ductile left-lateral shear 

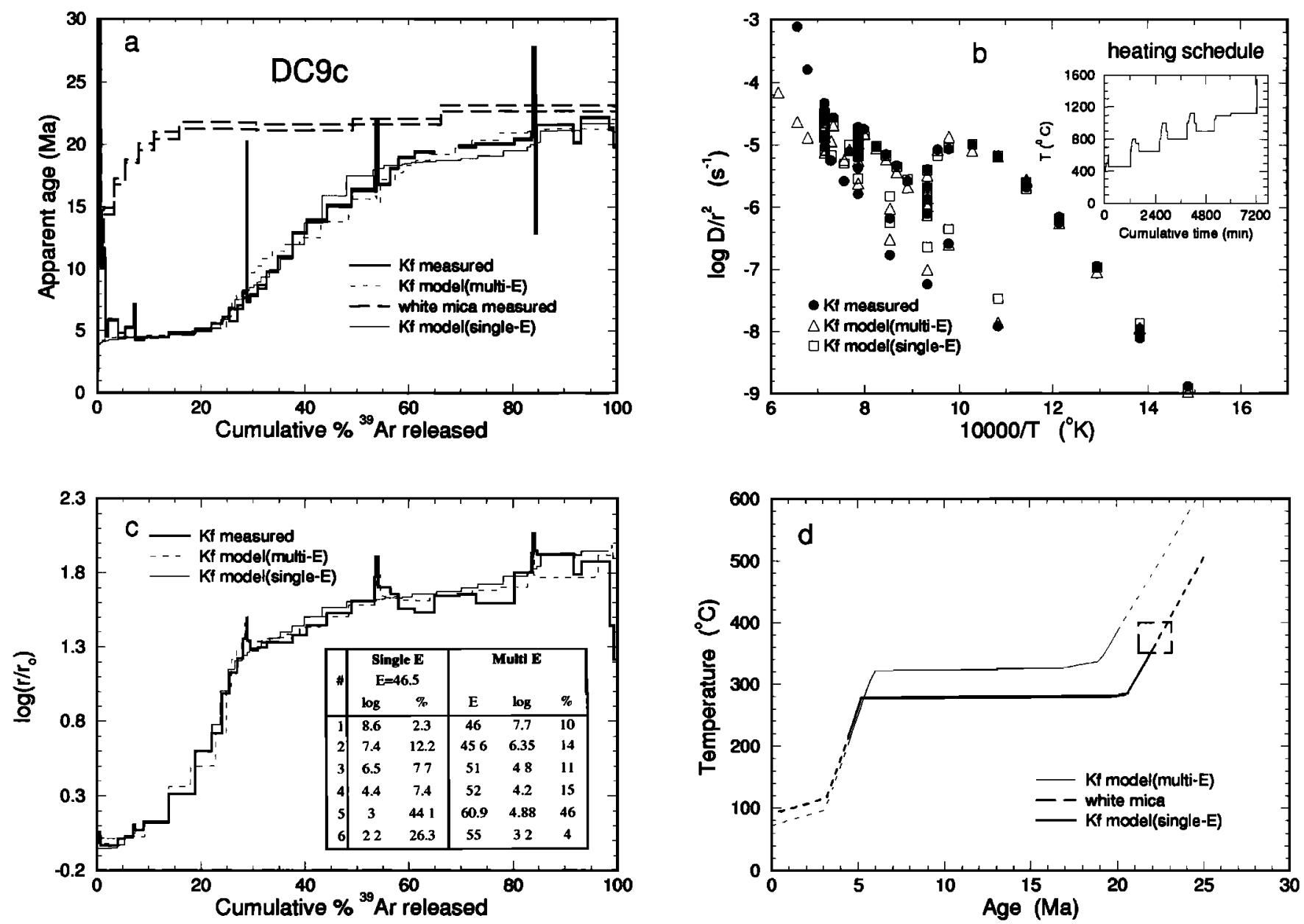

Fig. 15. (a) DC9c age spectra of K-feldspar (Kf) and white mica. The thin curve is the calculated $\mathrm{K}$-feldspar age spectrum using the activation energy, frequency-grain size parameter, and cooling history shown in (b) through (d) assuming a single activation energy ("single- $E^{\prime \prime}$ ). The age spectrum calculated assuming multiple activation energies ("multi- $E^{\prime \prime}$ ) is shown by a thin dashed line. (b) Arrhenius plot calculated from the experimental results (dots) assuming a plane slab diffusion model from measured ${ }^{39} \mathrm{Ar}$ loss during the step-heating experiment. The theoretical fits (open squares and triangles) arise from fitting the Arrhenius and $\log \left(r / r_{0}\right)$ results. The inset shows the heating schedule used to degas this sample. (c) Plot of $\log \left(r / r_{0}\right)$ versus $\%{ }^{30} \mathrm{Ar}$ released (heavy line) together with theoretical fit, both for the single-E (thin line) and the multi-E (thin dashed line) assumptions, using the values of $E$ and $\log \left(D_{o} / \rho^{2}\right)$ (indicated as "log") shown. (d) Proposed cooling history for DC9c that produces an excellent fit to the age spectrum (see Figure 15a).

zone during the mid-Tertiary [Tapponnier et al., 1990; Leloup, 1991].

However, the HT schistosity geometry is more complex at the southern termination than in the core of the Diancang Shan. In zone $A$, the character of deformation implies a normal/left-lateral sense of movement in a direction $\mathrm{N} 120^{\circ}, 25^{\circ} \mathrm{E}$ coeval with the HT schistosity and lineation. This can be interpreted as a late largescale, left-lateral, shear plane affecting the whole shear zone (Figure 21), comparable to C' planes observed at smaller scales [Berthé et al., 1979b]. A typical C' shear plane [Berthé et al., 1979b] would be vertical with a nearly horizontal shear direction and an angle of $\sim 30^{\circ}$ to the overall trend of the shear zone. The structure of the south Diancang Shan has a more complicated three- dimensional geometry: the shear plane dips $\sim 30^{\circ}$ to the south, the shear direction makes an angle of about $40^{\circ}$ with the overall strike of the shear zone, and plunges about $25^{\circ}$ towards the east-souteast. Note that this interpretation implies a vertical component on the large scale C' shear plane and an uplift of the northern block (i.e., the Diancang Shan massif). Large C' type shear planes affecting the shear zone appears common in the Ailao Shan to the south [Leloup, 1991].

LT structures. The LT structures are chlorite mylonites at the eastern end of zone A (sites A1 and A2 Figure 8), brittle chlorite slickensides and gouge in the eastern part of section B, and S-C structures at site DCS1. All LT structures on the northeast of the massif are close to the active normal fault and have roughly 

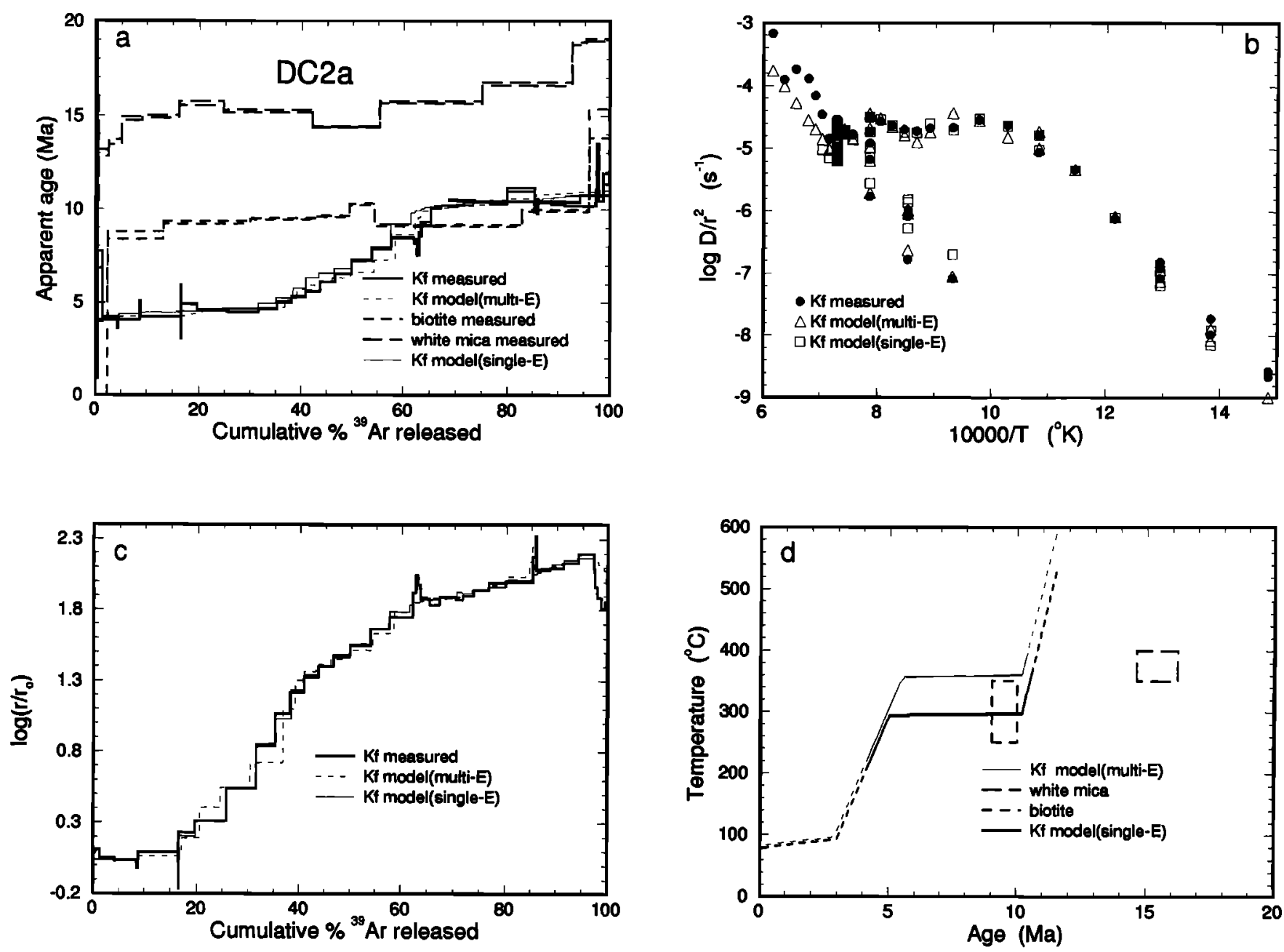

Fig. 16. (a) DC2a K-feldspar (bold line), biotite (short dashed) and white mica (dashed line) age spectra. (b) K-feldspar Arrhenius plot, (c) K-feldspar $\log \left(r / r_{0}\right)$ plot, (d) cooling history; the corresponding K-feldspar model age spectra are the light lines on Figure 16a. See Figure 15 for details.

similar orientations. The chloritization is more massive in the gneisses at site DCS1 than at sites A1 and A2. In both cases the lineation direction is nearly the same but the kinematic indicators give contradictory results: reverse faulting for site DCS1 and normal faulting for sites $\mathrm{A} 1$ and A2. It is nearly impossible to interpret opposite shear sense with the same orientation in terms of one stage of deformation, and thus the structures at site DCS1 probably correspond to a different tectonic regime than that of sites $\mathrm{A} 1$ and $\mathrm{A2}$.

The directions of extension, estimated from slickensides along section $B$ and from the chlorite lineations observed at sites $\mathrm{A} 1$ and $\mathrm{A2}$, are compatible with the extension direction deduced from the present normal faults and with the Quaternary strain field in this area (Figure 22a) [Allen et al., 1984]. The relative chronology of these structures is also compatible in that they both cut the HT fabric in the gneisses. These retrograde deformations might be due to ductile-to-brittle normal faulting after the left-lateral shearing (Figure 22b). Today, the relief of the Diancang Shan above the aver- age elevation of the surrounding region $(2200 \mathrm{~m})$ is $\sim 1800 \mathrm{~m}$. The total restored relief of the range since the onset of normal faulting may be estimated by adding to this figure an additional $2300 \mathrm{~m}$ that corresponds to the volume of rocks that have been eroded from the range and preserved in the Er Hai basin (Figure 22c). This estimate suggests that the Diancang Shan range was uplifted $\sim 4 \mathrm{~km}$ since the beginning of deposition in the Er Hai basin. This should be considered a minimum estimate of the total uplift since filling of the basin may not have begun until significant topography had been attained. The age of the older sediments in the Er Hai basin is not precisely known but is thought to be lower Quaternary (Figure 3c) [Guo et al., 1986]. If we assume that deposition started at the beginning of the Quaternary, we obtain an uplift rate of $\sim 2 \mathrm{~mm} / \mathrm{yr}$, similar to the rate of active normal faulting estimated by Allen et al. [1984].

The reverse shear sense recorded by gneisses at site DCS1 cannot be interpreted in terms of either leftlateral shearing or normal faulting. The gneisses at 

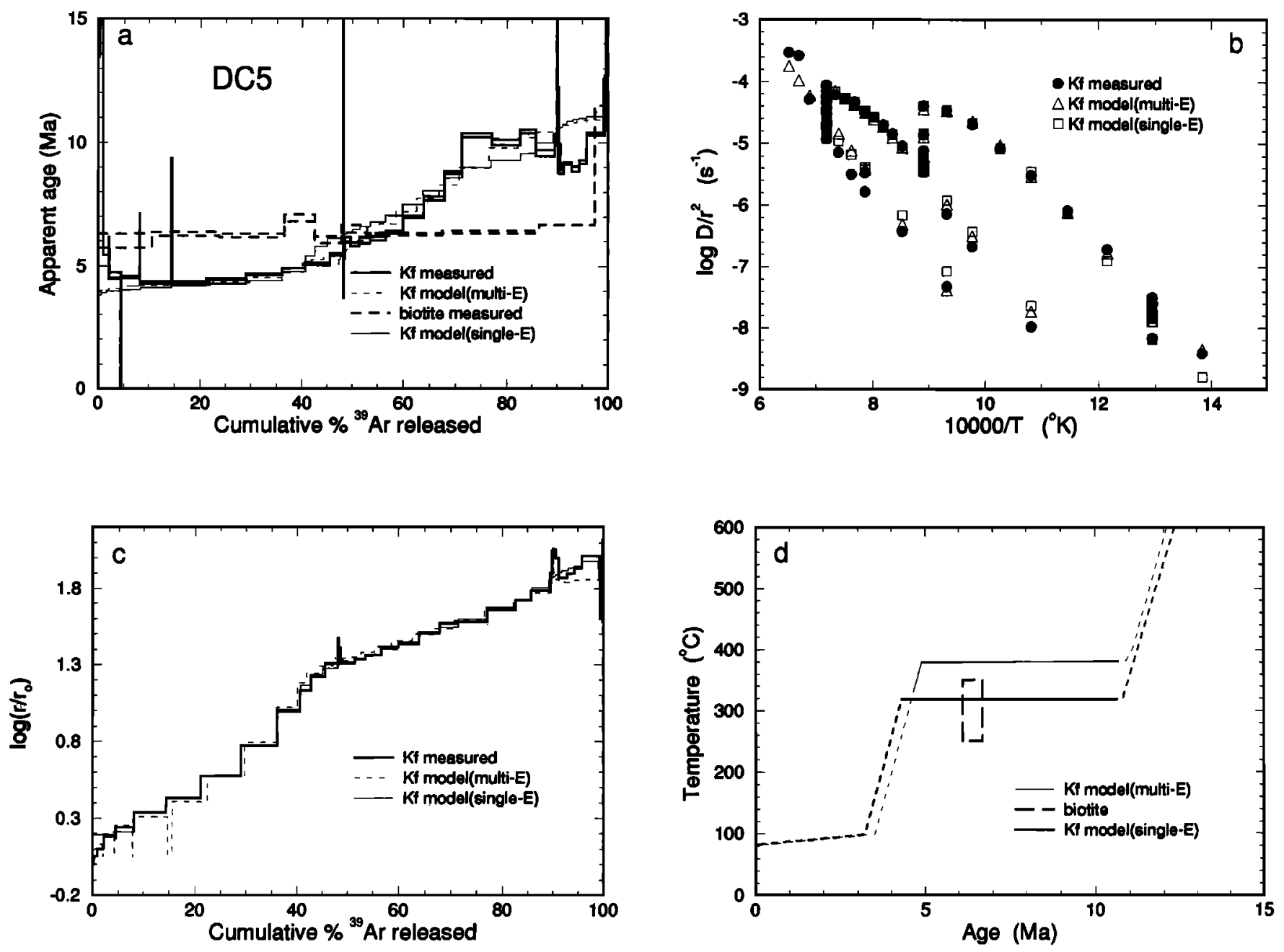

Fig. 17. (a) DC5 K-feldspar (bold line) and biotite (short dashed) age spectra, (b) Kfeldspar Arrhenius plot, (c) K-feldspar $\log \left(r / r_{0}\right)$ plot, $(d)$ cooling history; the corresponding $\mathbf{K}$-feldspar model age spectra are the light lines on Figure 17a. See Figure 15 for details.

this site (Figure 2) probably correspond to an older decollement level, perhaps like most of the gneisses in the northeastern part of the Diancang Shan.

Based on the observations presented above, we separate the structural history of the Diancang Shan into three distinct tectonic stages.

1. A thrusting(?) event of unknown age (Hercynian or Indosinian?) is only documented at site DCS1. It appears to predate stages 2 and 3.

2. A left-lateral stage of deformation forms the HT schistosities and lineations in a northwest-southeast oriented ductile shear zone. This stage can itself be separated into two successive steps: formation of a simple strike-slip shear zone identical to those visible in the Ailao Shan massif farther to the south, followed by the formation of a large left-lateral C' shear plane dissecting the whole shear zone. The direction of movement on this later shear plane has a vertical component (dip of $25^{\circ}$ toward the east-southeast), and thus implies some uplift of the Diancang Shan massif.

3. The shear zone is uplifted in a horst between $t-$ wo presently active normal faults with a right-lateral component. The mylonites at sites $\mathrm{A} 1$ and $\mathrm{A2}$ may be ductile parts of this normal fault uplifted in the footwall of the fault (Figure 22b). This normal fault may have been initiated at the same time as the right-lateral Red River fault.

The above interpretation predicts two distinct phases of uplift of the Diancang Shan: one at the end of the left-lateral deformation (after $\sim 24 \mathrm{Ma}$ ) and another recent, and still active, phase.

\section{Implications of the P-T-t Path}

The principal conclusion that can be drawn from the garnet P-T path analysis is that the later stages of garnet growth within the Diancang Shan took place during a period of essentially isothermal decompression $(\Delta \mathrm{T}$ $\sim 40^{\circ} \mathrm{C}$ ). The inferred geothermal gradient varies from about $22^{\circ} \mathrm{C} / \mathrm{km}$ (recorded by the high-pressure end of the P-T path) to $34^{\circ} \mathrm{C} / \mathrm{km}$ (recorded by the garnet rim/matrix assemblage). It appears that development of the HT fabric was still continuing after termination of garnet growth at $\sim 570^{\circ} \mathrm{C} / 5$ kbar. 

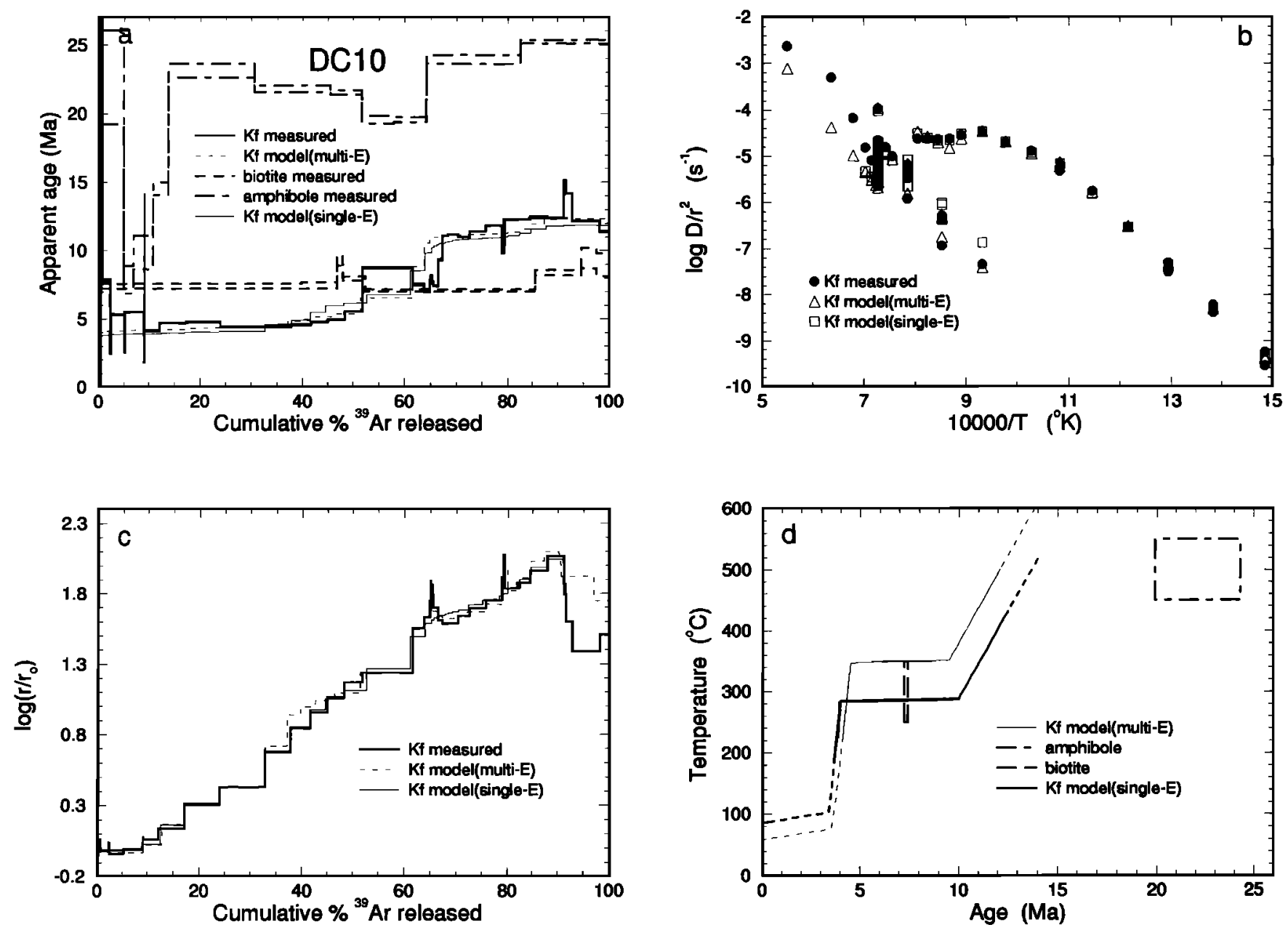

Fig. 18. (a) DC10 K-feldspar (bold line), biotite (short dashed) and amphibole (dot dashed) age spectra, (b) K-feldspar Arrhenius plot, (c) K-feldspar log ( $\left.r / r_{0}\right)$ plot, (d) cooling history; the corresponding $K$-feldspar model age spectra are the light lines on Figure 18a. See Figure 15 for details.

Our calculated peak thermal gradient of $30-35^{\circ} \mathrm{C} / \mathrm{km}$ is lower than the estimate of $40^{\circ} \mathrm{C} / \mathrm{km}$ made by Leloup and Kienast [1993] for the Ailao Shan but still suggests that high values were reached, if only briefly, during metamorphism. Because the peak temperature recorded by the prograde assemblage of Leloup and Kienast [1993] reached $700^{\circ} \mathrm{C}$, a potential criticism of their result is that isothermal decompression could have permitted the garnet-plagioclase-aluminosilicate barometer to have continually reequilibrated until significant cooling occurred. This would have the effect of underestimating peak pressure and overestimating the equilibrium geotherm. If the P-T path obtained here is typical of the other massifs, we cannot rule out such a scenario. Since southern Yunnan was apparently not substantially thickened during the mid-Tertiary, we cannot call upon transient heating due to overthrusting to explain our elevated geotherm. Rather, it would seem that the higher apparent geotherm reflects rapid denudation (the pressure drop recorded by the P-T path corresponds to about $\sim 7 \mathrm{~km}$ of unroofing) of a terrane initially along a geotherm of $\sim 20-25^{\circ} \mathrm{C} / \mathrm{km}$. For reference, the presentday heat flow in the region of the Diancang Shan is about $90 \mathrm{~mW} / \mathrm{m}^{2}$ [Wu et al., 1988].

Based upon the age of anatectic granitoids, peak temperature conditions were probably reached in the Diancang Shan at $24.4 \pm 0.2 \mathrm{Ma}$ [Liu et al., 1992] whereas the temperature had dropped below $\sim 500^{\circ} \mathrm{C}$ (the closure temperature of hornblende) by $22 \pm 2 \mathrm{Ma}$ (DC10a amphibole). Thus the pressure drop of $2 \mathrm{kbar}$ recorded by the garnet zoning suggests a minimum estimate of unroofing rate between 24.6 and $\sim 20 \mathrm{Ma}$ of $\sim 1.5$ $\mathrm{mm} / \mathrm{yr}$.

Although lithospheric extension is a common source of elevated geotherms, the dominant state of stress (i.e., strike-slip) effectively rules out this possibility. Rather, this very environment makes strain heating an appealing mechanism [e.g., Molnar and England, 1990]. Our expectation of the strength of the crust during lithospheric scale strike-slip faulting suggests that strain heating would be concentrated near the base of the brittle layer and immediately beneath the Moho [Sib- 

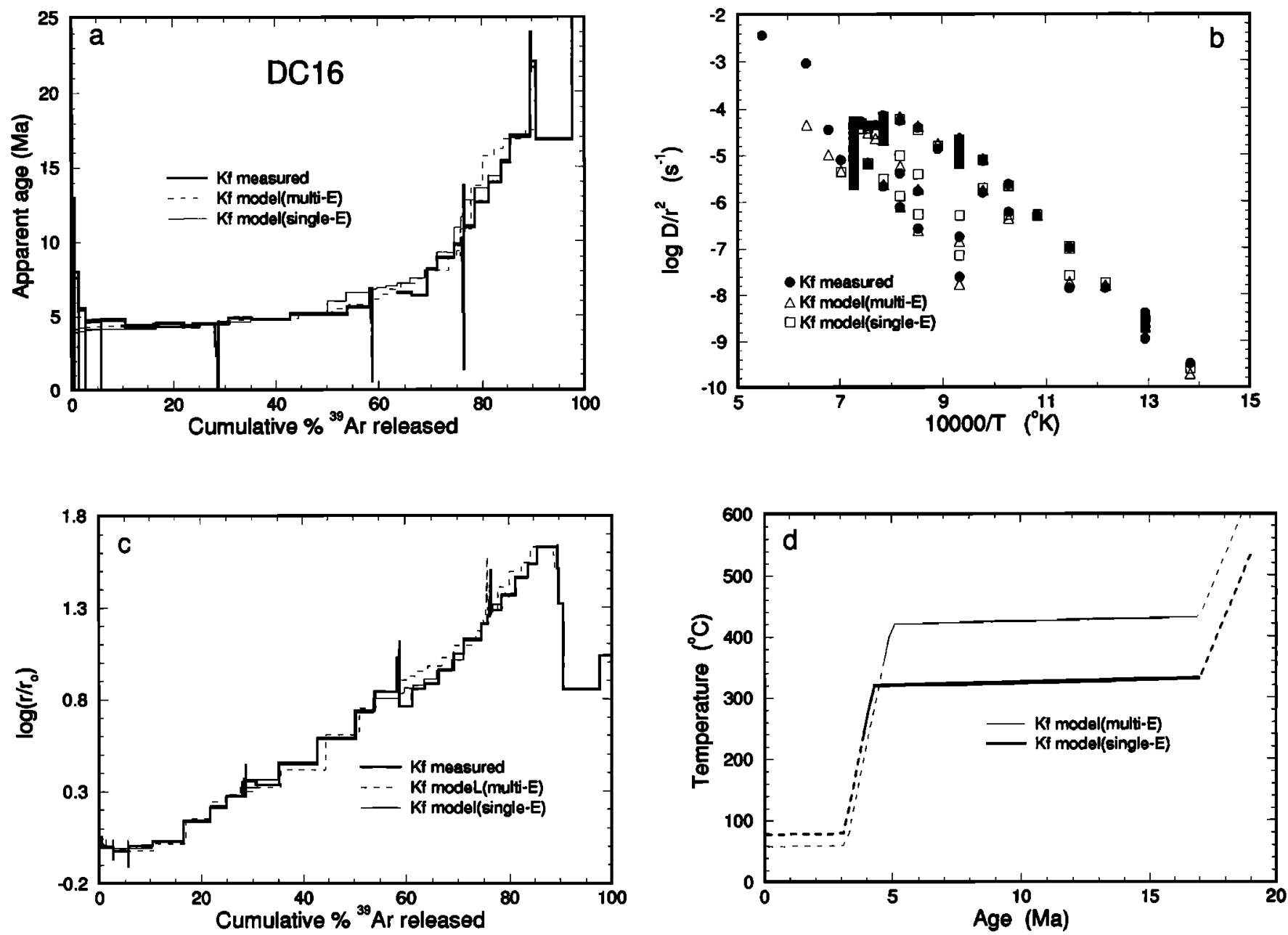

Fig. 19. DC16 K-feldspar (a) age spectrum, (b) Arrhenius plot, (c) $\log \left(r / r_{0}\right)$ plot, (d) cooling history; the corresponding $K$-feldspar model age spectra are the light lines on Figure 19a. See Figure 15 for details.

son, 1977]. The contribution to warming the middle crust from frictional sliding just above the brittleductile transition would be realized essentially immediately upon initiation of faulting. However, considerable time would pass before the heat generated just below the crust-mantle boundary reaches the depth range recorded by our samples $(\sim 15-20 \mathrm{~km})$. If heat transfer across this $20-\mathrm{km}$ interval were entirely conductive, then the characteristic time scale for transport would be about $10 \mathrm{~m} . \mathrm{y}$. This lag time is similar to the duration between initial rifting in the South China Sea $(\sim 35 \mathrm{Ma})$ and achievement of peak metamorphic conditions in the Ailao Shan at $\sim 23 \mathrm{Ma}$ [Schärer et al., 1990; Leloup and Keinast, 1993]. Thus heating of the midcrust may have been due to the growing influence of heat generated $20-25 \mathrm{~km}$ beneath the presently exposed rocks between $\sim 35$ and $20 \mathrm{Ma}$.

\section{Significance of the Thermal Histories}

All the thermal history results obtained from ${ }^{40} \mathrm{Ar} /{ }^{39} \mathrm{Ar}$ data are summarized on Figure 23 . The $\mathrm{K}$ - feldspar thermal histories share two features; an essentially isothermal phase lasting between 5 and $15 \mathrm{Ma}$ followed by rapid cooling beginning at $\sim 5 \mathrm{Ma}$. The most precise estimate of the onset of rapid cooling is 4.7 $\pm 0.1 \mathrm{Ma}$, the mean and standard error of the age plateaus from the six K-feldspars (Figures 14 and 23). The K-feldspar cooling histories are broadly compatible with the coexisting muscovite, biotite, and amphibole ages obtained. It is interesting to note that there is no obvious correlation between sample location and cooling history. This suggests that thermal events were nearly synchronous at the scale of our study. However, sample DC9c, the only sample of LT gneisses (site A2, Figure 8), appears to us to be allocthonous as it began to close with respect to argon loss much earlier than the other samples. It also appears to begin the late Miocene cooling slightly before the other samples (Figure 23). All K-feldspar thermal histories are characterized by an isothermal stage that is well constrained by the age spectra. Temperatures of the isothermal phase vary between $270^{\circ} \mathrm{C}$ (DC28) and $\sim 320^{\circ} \mathrm{C}$ (DC16) with an average of all samples just prior to rapid cooling of 

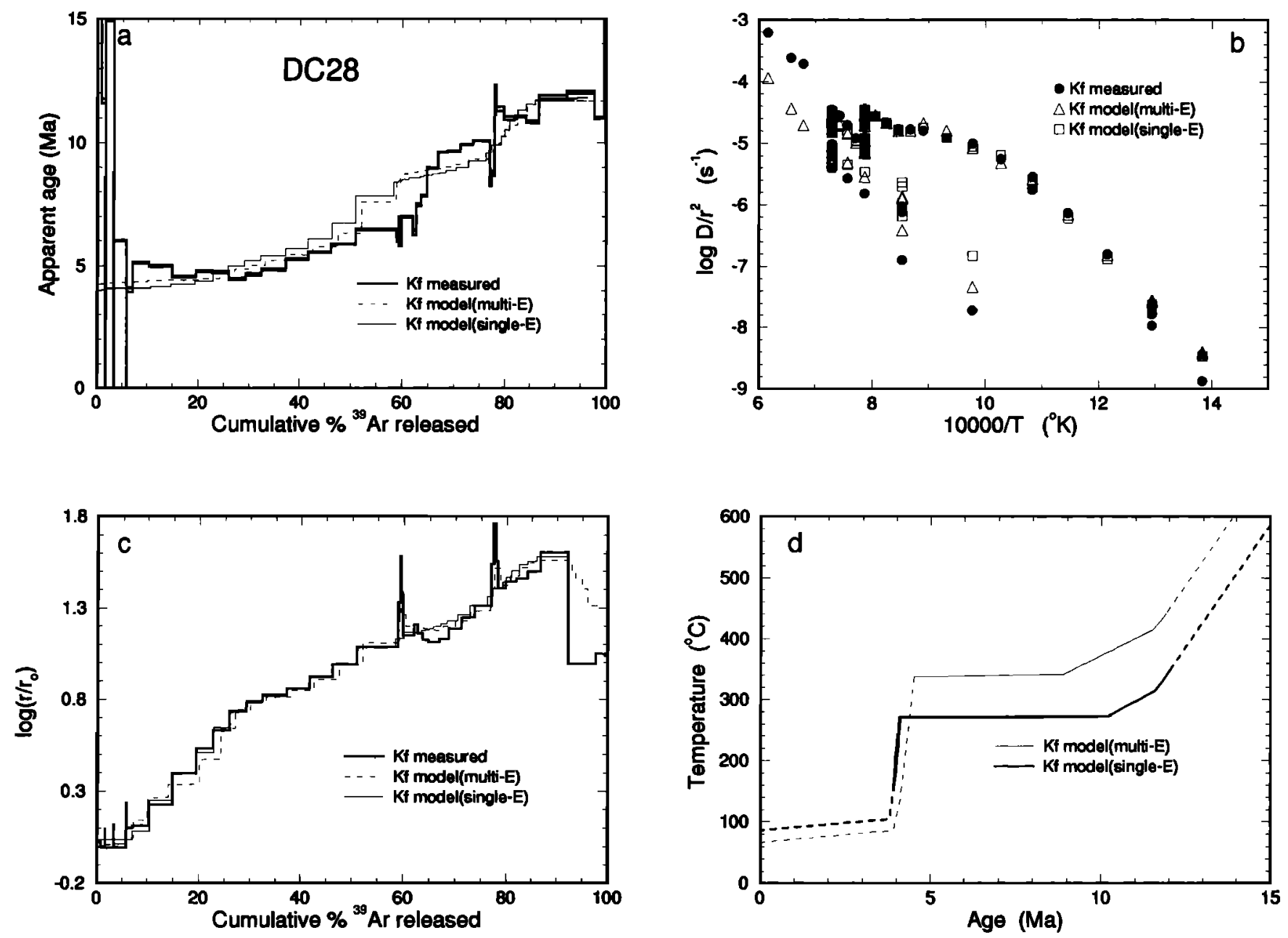

Fig. 20. DC28 K-feldspar (a) age spectrum, (b) Arrhenius plot, (c) $\log \left(r / r_{0}\right)$ plot, (d) cooling history; the corresponding $\mathbf{K}$-feldspar model age spectra are the light lines on Figure 20a. See Figure 15 for details.

$295 \pm 20^{\circ} \mathrm{C}(1 \sigma)$ (Figure 23). This coherence is remarkable given that the samples were collected from elevations that differ by $\sim 1700 \mathrm{~m}$. Most of the K-feldspars also appear to show an earlier cooling episode, but this, at least in some cases, may be an artifact resulting from the insensitivity of input cooling history immediately prior to closure of the most retentive domain. Based upon $\mathrm{U}-\mathrm{Pb}$ monazite ages of an anatectic granitoid in section $\mathrm{B}$, temperatures higher than $650^{\circ} \mathrm{C}$ were reached in portions of the Diancang Shan at $24.4 \pm 0.2 \mathrm{Ma}$ [ Liu et al., 1992]. ${ }^{40} \mathrm{Ar} /{ }^{39} \mathrm{Ar}$ results indicate that temperature had dropped below $\sim 500^{\circ} \mathrm{C}$ (the closure temperature of hornblende) by $22 \pm 2 \mathrm{Ma}$ (DC10a amphibole) and below $330^{\circ} \mathrm{C}$ by $17 \mathrm{Ma}$ (DC16 K-feldspar) (Figure 23). This confirms the occurrence, at least in this part of the massif, of an early Miocene phase of cooling of the order of $50^{\circ} \mathrm{C} / \mathrm{m}$.y. (Figure 23 ).

\section{P-T-t Evolution of the Diancang Shan Massif}

The cooling histories shown on Figure 23 are broadly consistent with the proposed structural model. The two periods of rapid cooling may correspond to the two proposed stages of uplift: (1) during the activation of the large C' shear plane at the end of the left-lateral deformation, and (2) along the still active normal faults bounding the massif.

The earlier cooling episode may be due to the activation of a large-scale $C^{\prime}$ shear plane that dismembered the shear zone at the end of the left-lateral deformation. According to the cooling history of the massif, temperatures of $550^{\circ} \mathrm{C}$ (corresponding to the pressure drop of 2 kbar recorded by the DC-3 garnet rim zoning) were attained at $\sim 23 \mathrm{Ma}$ (Figure 23). The fact that this drop in pressure is nearly isothermal may be explained by very rapid denudation that lasted less than $4 \mathrm{~m}$.y. (unroofing rate of $\sim 2 \mathrm{~mm} / \mathrm{yr}$ ). Due to the vertical component of movement along the C' large-scale shear plane (lineation dip of $25^{\circ}$ ), high uplift rates are expected in zone A where DC3 has been sampled. If the uplift of $\sim 7 \mathrm{~km}(2 \mathrm{kbar})$ recorded in DC3 garnet is due to this mechanism, this would require $\sim 15 \mathrm{~km}$ of left-lateral displacement along the large-scale shear plane (direction of movement $\mathrm{N} 120^{\circ}$ ). If this structure 


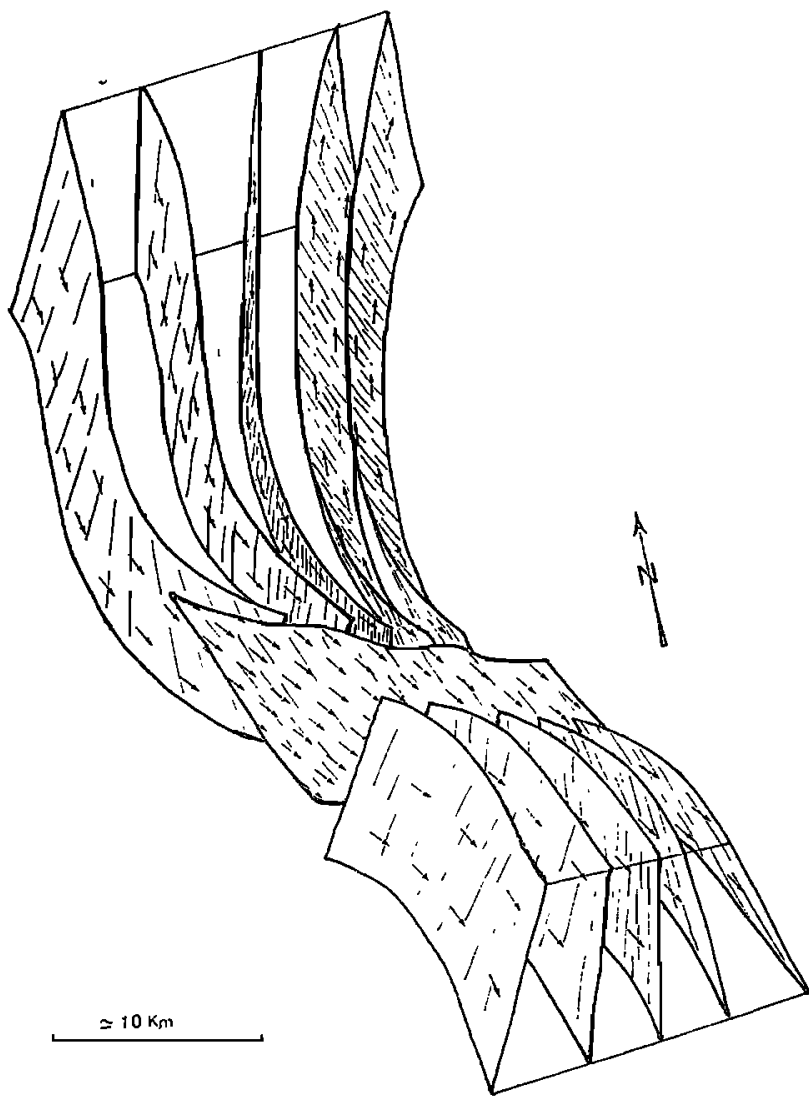

Fig. 21. Interpretative sketch of the three-dimensional shape of the schistosity in the Diancang Shan massif. HT schistosity and lineation left-lateral related to the left-lateral shear is affected by HT schistosity and lineation related to leftlateral/normal C' shear plane probably active during the last left-lateral movements.

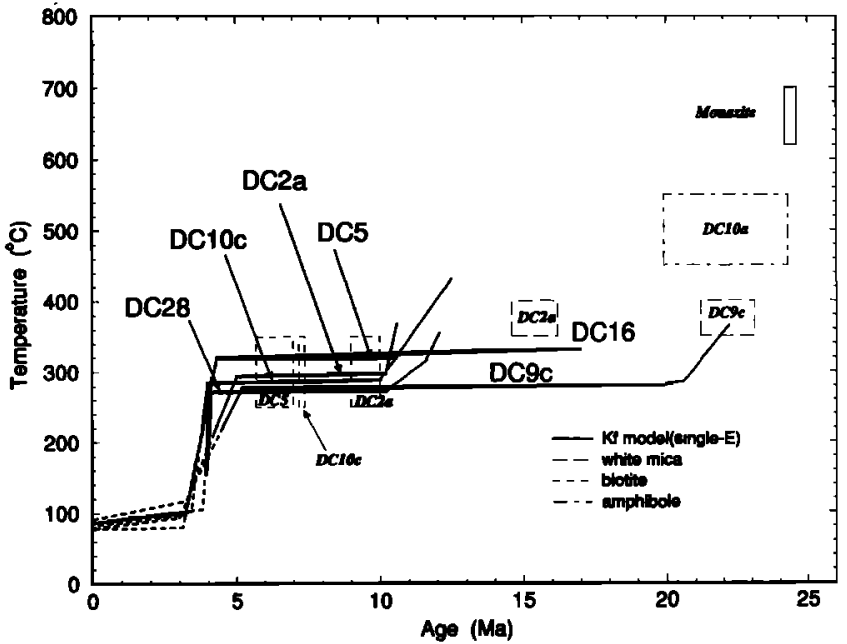

Fig. 23. Summary of all thermal history results from the Diancang Shan samples. Monazite $\mathrm{U} / \mathrm{Pb}$ result from $L$ iu et al. [1992]; all other results from this study. The Kf cooling histories are those assuming a single activation energy (single $-E$ ).

continued to be active until the end of the cooling event $\left(\sim 17 \mathrm{Ma}\right.$ and $\left.290^{\circ} \mathrm{C}\right)$ with the same geometry and a transient geothermal gradient of $\sim 30^{\circ} \mathrm{C} / \mathrm{km}$ (elevated due to denudation), it may have induced as much as $\sim 10 \mathrm{~km}$ of uplift corresponding to $\sim 20 \mathrm{~km}$ of horizontal offset. This offset may, in part, explain the absence of metamorphic rocks along the Midu Gap (Figure 1) (see discussion below). Alternatively, the first phase of uplift may be due to continued left-lateral displacement along the Red River fault zone but with a normal component of movement beginning at $\sim 20 \mathrm{Ma}$. Harrison
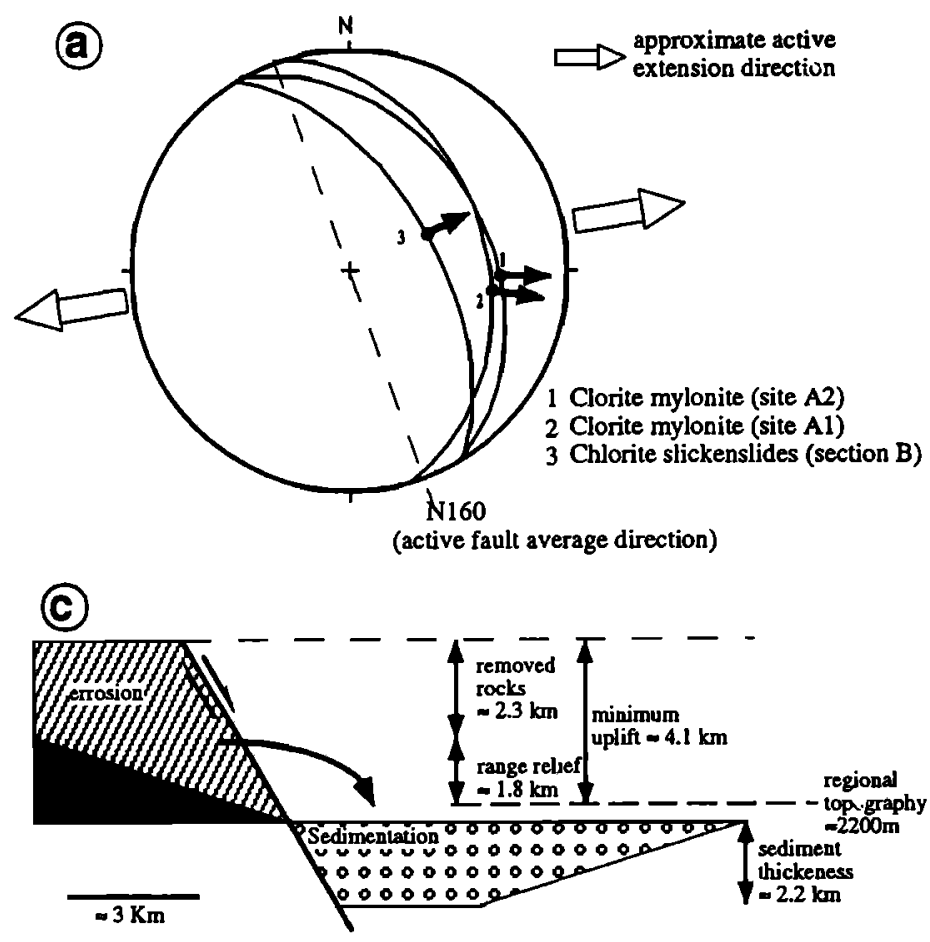

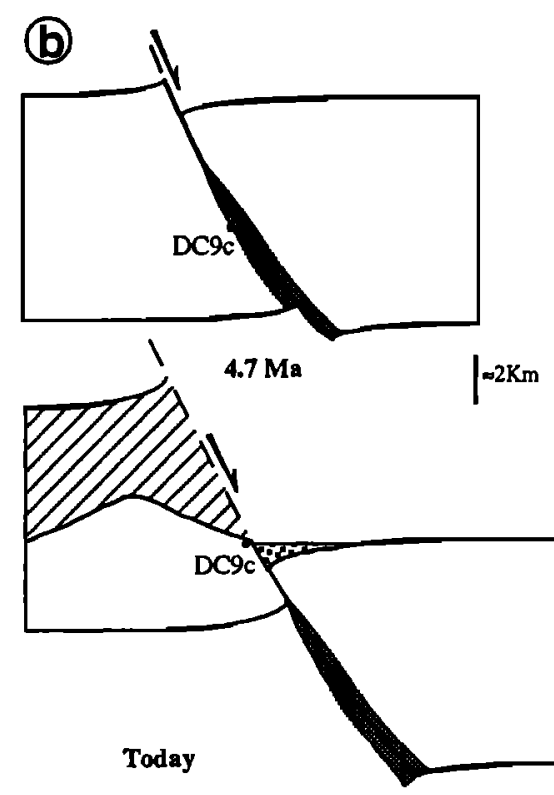

Ductile deformation

Fig. 22. LT normal fault structures of the eastern flank of the Diancang Shan. (a) Projection of all LT structures of the Diancang Shan. Schmidt diagram, lower hemisphere projections. (b) Interpretative sketch of the uplift of LT normal mylonite at the wall of the active normal fault. (c) Estimate of the uplift due to the active normal fault. 

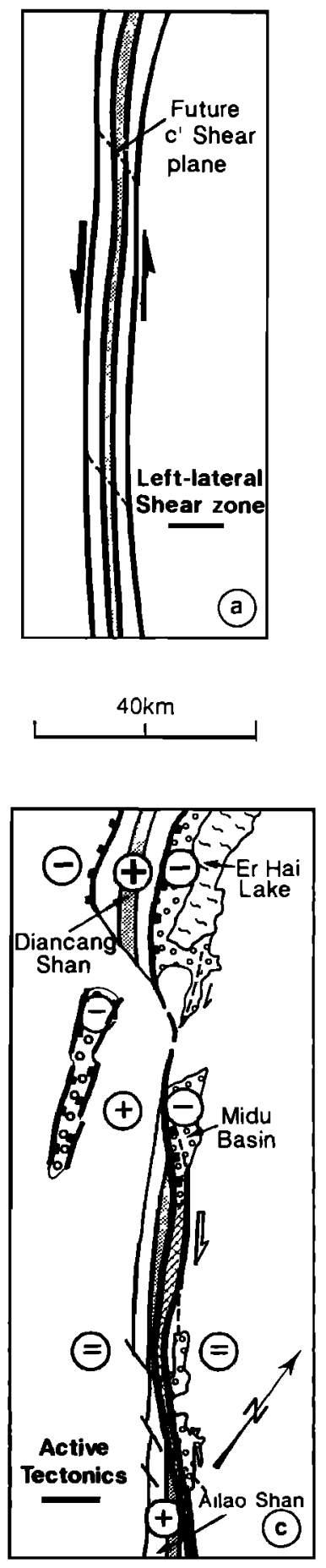
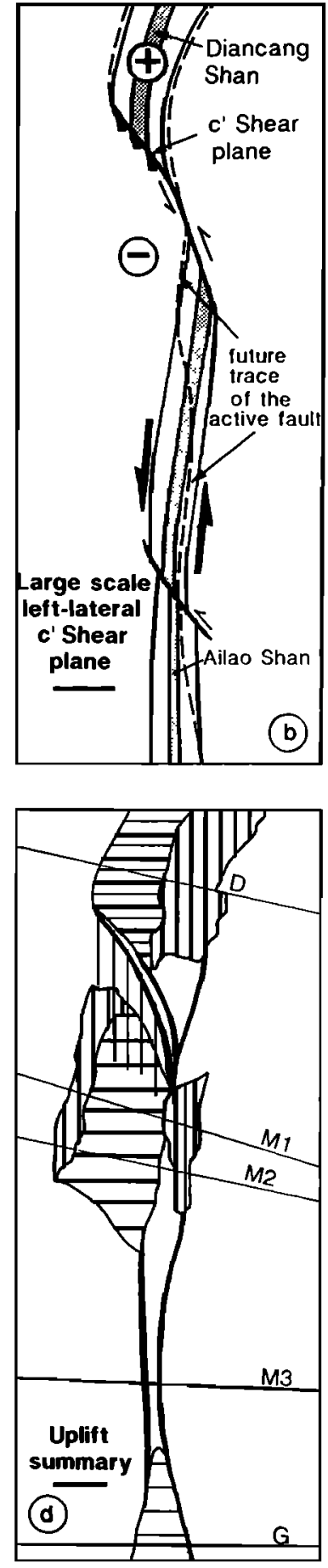
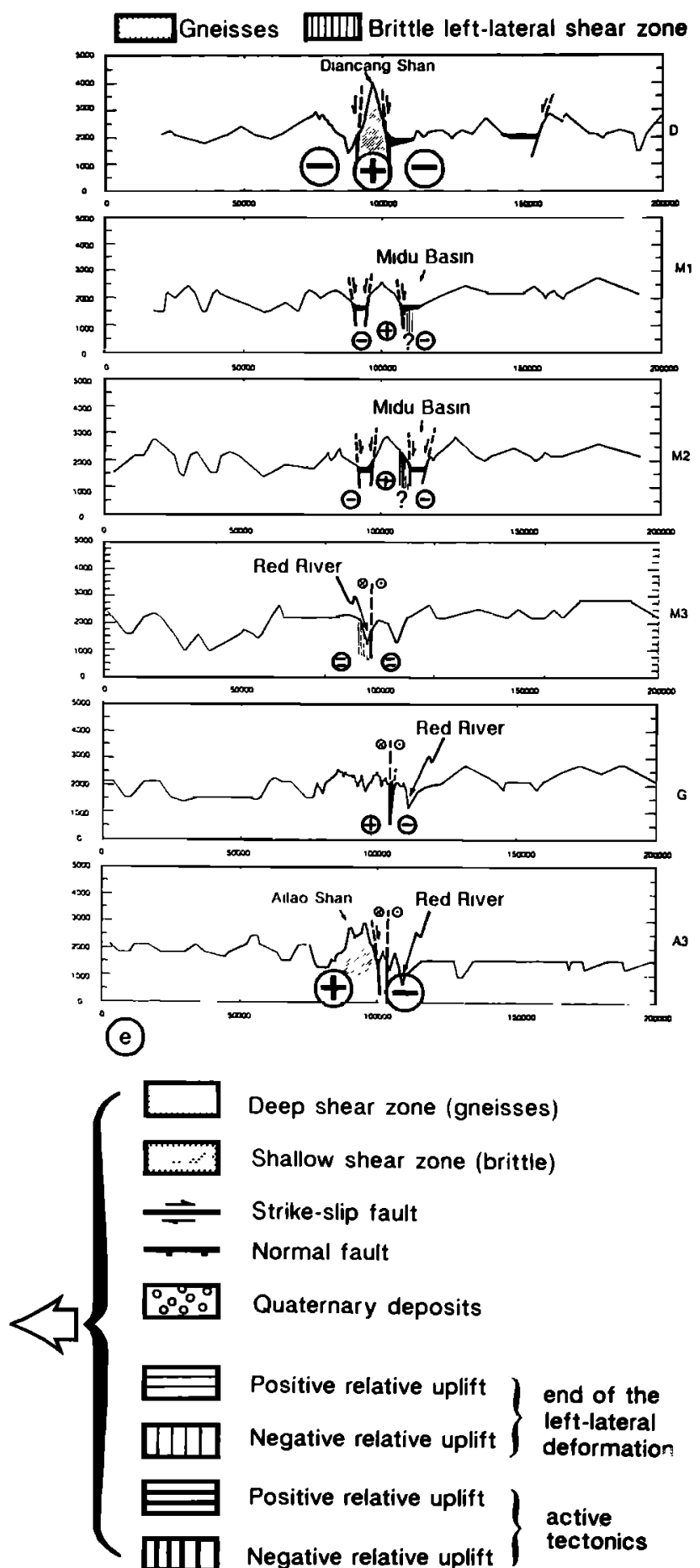

Fig. 24. Interpretative sketches of the structural evolution of the "Midu Gap". (a) Continuous left-lateral ductile shear zone. (b) Large-scale left-lateral C' shear planes affecting the shear zone. (c) Active faults: normal on each side of the Diancang Shan, right-lateral south of Midu, right-lateral and normal at the northern end of the Ailao Shan. (d) Qualitative summary of corresponding total uplift. The topographic sections DCS1, M1, M2, $\mathrm{M3}$, and $\mathrm{G}$ are shown on Figure 24e. Section $\mathrm{A3}$ is located farther south near the town of Gasa. Metamorphic rocks outcrop where the total uplift is greater. (e) Qualitative estimation of recent uplift along sections across the Red River fault. Sections are located on Figure 24d. Topography from Chinese $1 / 100,000$ scale topographic maps and ONC maps. The vertical exaggeration is $10 \mathrm{x}$.

et al. [1992a] concluded that extension was active in the Ailao Shan during the early Miocene coevally with left-lateral shearing, and to a lesser extent, the same forces may have been extant in the Diancang S'an at that time. Furthermore, many K-Ar ages of illitic fault go' ge from along the active faults cluster at about 20 Mo [Harrison et al., 1992a]. For example, four analyses of two samples south of Dali yield an age of $21.5 \pm 0.9$ $\mathrm{Ma}$ (Li Qi, unpublished data, 1993). It seems difficult to argue that the fault gouge is a late Neogene product 
contaminated with older material as not one of the over three dozen ages is younger than $20 \mathrm{Ma}$. Ambient temperatures of the gneisses were $\sim 300^{\circ} \mathrm{C}$ at $20 \mathrm{Ma}$, and because this temperature approaches both the stability limit of $1 \mathrm{Md}$ illite and a liberal estimate of its thermal stability for argon [Lyons and Snellenburg, 1971], we conclude that the gouge present in outcrop today was probably carried down from shallower depths on the hanging wall surface of a normal fault already active at $20 \mathrm{Ma}$. The two mechanisms that may explain uplift at the end of the left-lateral deformation are not incompatible and may have occurred simultaneously or successively in a short time period (>8 m.y.).

The thermal histories calculated from the isotopic results (Figure 23) are all characterized by a nearly isothermal phase that lasts from 17 to $19 \mathrm{Ma}$ (DC9c and DC16) or 10 to $12 \mathrm{Ma}$ (all other samples) until $\sim 5$ Ma. We interpret this phase to correspond to a period during which both no significant unroofing occurred and the geothermal flux remained essentially constant.

The cause of the rapid cooling beginning at $4.7 \mathrm{Ma}$ was very likely initiation of the presently active normal faulting. The footwall was then cooled both by exhumation and the refrigerating effect of the cold hanging wall. The lag time between initiation of significant fault motion and thermal equilibration of samples, all within $4 \mathrm{~km}$ of the refrigerating surfaces (normal faults bound both side of the massif), is expected to be less than about $1 \mathrm{~m}$.y. This is consistent with our ${ }^{40} \mathrm{Ar} /{ }^{39} \mathrm{Ar}$ results that indicate that rapid cooling at all sample locales was occurring at $4.7 \pm 0.1 \mathrm{Ma}$ and with stratigraphic data that indicate fault motion and fault related basin fill beginning in the late Neogene [Guo et al., 1986; Allen et al., 1984]. Alternatively, to explain these data as reflecting surface denudation would require very rapid rates $(>3 \mathrm{~km} / \mathrm{m}$.y. assuming a thermal gradient of $30^{\circ} \mathrm{C} / \mathrm{km}$ ). If the sediments of the Er Hai lake basin started to be deposited at $4.7 \mathrm{Ma}$, the minimum uplift value of $4 \mathrm{~km}$ corresponds to a minimum average uplift rate of $1 \mathrm{~mm} / \mathrm{yr}$. If the thermal gradient $\left(\sim 30^{\circ} \mathrm{C} / \mathrm{km}\right)$ did not change in the area since the initiation of the normal faulting, this fault could have absorbed about 10 km uplift (i.e., the depth corresponding to temperatures between 320 and $270^{\circ} \mathrm{C}$ at the beginning of the cooling event, Figure 23). This would correspond to higher denudation rates of $\sim 2 \mathrm{~mm} / \mathrm{yr}$. As crystal-plastic flow of quartz-feldspar lithologies is not expected at temperatures below $300^{\circ} \mathrm{C}$, Harrison et al. [1992a] concluded that ductile shearing in the gneisses presently exposed further to the south in the Ailao Shan had ceased between 22 and $19 \mathrm{Ma}$. In the Diancang Shan, the shape of the cooling history makes it difficult to know precisely when this temperature was reached. Temperatures of all sample drop below $250-300^{\circ} \mathrm{C}$ shortly after $5 \mathrm{Ma}$. LT mylonites observed at sites $\mathrm{A} 1$ and $\mathrm{A2}$ may correspond to the ductile part of the normal fault, formed in the earlier stage of movement on this fault. This mylonites may have been progressively uplifted (and eventually slightly rotated) at the footwall of this fault (Figure 22).

\section{Relationship Between the Diancang Shan and Ailao Shan}

The Diancang Shan and the Ailao Shan ranges are separated by the 80-km-long "Midu Gap," a left-lateral brittle fault zone of $\mathbf{5} \mathbf{~ k m}$ width (Figure 1) [Tapponnier et al., 1990; Leloup, 1991]. The structural history of the Diancang Shan we propose (Figures 24a-24c) offers an explanation as to why the left-lateral deformation is exposed in a higher structural level along the Midu Gap. The two last stages of deformation described above (late left-lateral/normal C' shear plane and active right-lateral/normal faulting) implies differential uplift of parts of the early ductile left-lateral shear zone that outcrop where the total uplift is greater. The qualitative amount of these uplifts and the total result are summarized in Figure 24.

During the activation of the large-scale C' shear plane that dismembered the shear zone the Diancang Shan was uplifted relative to the area to the south (Figure 24b). An estimate of the later amount of recent uplift along the active faults can be obtained from the topographic roughness as high range elevation is an indication of recent uplift (Figure 24e). The northern end of the Ailao Shan massif corresponds to the disappearance of the component of normal slip on the active Red River right-lateral/normal fault (Figure 24c) [Leloup, 1991]. Active faulting along the Midu Gap is characterized by two different styles: pure right-lateral slip just north of the Ailao Shan and normal faults bounding small basins farther to the north (Figure 24c). While to the south the amount of recent uplift on the Red River fault appears to be negligible (Figure 24e), the area between the two basins to the north appears to have experienced a small amount of recent uplift but was down dropped during the previous phase of deformation (Figure 24d). The Diancang Shan massif was uplifted during both tectonic stages (Figure 24d).

Our model assumes an offset of the shear zone along the late left-lateral C' shear-plane of $20 \mathrm{~km}$ (Figure 24b) and a recent right-lateral offset of the Red River fault of $9 \mathrm{~km}$ or more (Figure 24c). As recent right lateral offset of at least $9 \mathrm{~km}$ has been documented [Allen et al., 1984], this model gives a plausible explanation why the left-lateral deformation is ductile in the Ailao Shan and Diancang Shan Ranges, brittle on section M3, and is not visible along section M1 (Figure 24d) and appears to confirm the view that the Diancang Shan and the Ailao Shan are parts of the same left-lateral shear zone.

\section{Conclusions}

An integrated program of structural, thermobarometric, and thermochronological analyses addressed the following questions related to the evolution of the Diancang Shan massif. When did left-lateral ductile shear cease? Did significant unroofing of the shear zone occur during the left-lateral deformation? Is the Diancang Shan a continuation of the Ailao Shan in the Red River shear zone? What was the timing of the onset of normal/right-lateral faulting?

We conclude that the Diancang Shan is a prolongation of the Ailao Shan along the Red River shear zone. In the Diancang Shan, left-lateral deformation occurred at least until 20-24 Ma. As was previously shown for the Ailao Shan, some portion of the unroofing occurred toward the end of the left-lateral activity (about $7 \mathrm{~km}$ between 23 and $19 \mathrm{Ma}$ ) that we ascribe to activation of a large-scale oblique $C^{\prime}$ shear plane that dismembered 
the shear zone. The activity of this left-lateral shear plane appears to have ended at 19-17 $\mathrm{Ma}$ as an essentially isothermal phase begins at this time. This may be compared with the date of cessation of seafloor spreading in the South China Sea that is thought to have occurred between 16 and $17 \mathrm{Ma}$ [Taylor and Hayes, 1980, 1983; Briais, 1989; Briais et al., 1993]. Cooling associated with the onset of normal/right-lateral faulting along the Diancang Shan (and perhaps, activation of the right-lateral/normal movement on the Ailao Shan Range Front fault) appears to have begun at $4.7 \pm 0.1$ Ma.

These results support the view that extrusion of Indochina occurred along the left-lateral Red River shear zone between about 35 and 17-19 Ma. If extrusion occurred, crustal shortening in southern Tibet would have been forestalled until motion on the shear zone terminated. This could in part explain the rapid unroofing throughout the Himalaya and southern Tibet that began in the early Miocene [e.g., Harrison et al., 1992b]. Initiation of right-lateral slip may be a consequence of eastward directed crustal flow from the thickened Tibetan lithosphere [Dewey, 1988; Bird, 1991; England and Houseman, 1989], thought to have achieved its maximum elevation between $5 \mathrm{Ma}$ and $7 \mathrm{Ma}$ [e.g., Mercier et al, 1987; Harrison et al., 1992b], or more probably marks the beginning of a second phase of extrusion [e.g., Tapponnier et al., 1986]. The effect of eastward spreading in the Yangtze block could either directly produce right-lateral slip, or cause, by clockwise rotation of the shear zone, the appearance of rightlateral motion.

Acknowledgments. This research was supported by grants to T.M.H. (NSF EAR-9103324 and DoE/BES DEFG03-89ER14049), F.J.R. (DoE/BES W-7405-E NG-48 and IGPP/LLNL), and C.W. (Seismological Foundation of the People's Republic of China and Open Laboratory Fund). P.H.L., P.T., and R.L. acknowledge the IPGP, DBT program of CNRS-INSU, and Academie Sinica-CNRS Cooperative Project for support (this is IPGP contribution $\mathbf{n}^{\circ}$ 1238). We thank Matt Heizler for technical assistance with the argon isotopic analyses; Frank Spear for advice with the P-T modelling; Oscar Lovera for developing the automation codes; Gary Cook for facilitating the neutron irradiations; and Matt Kohn for an incisive and thorough review. $X$ ue Xiao-Feng (Yunnan Institute of Geological Sciences) is thanked for accompanying us in the field and collection of samples. Special thanks to Mr. Berton Woodward for a Sunday morning well spent; to Sally Spengler R.N. and Asia Emergency Assistance for delivering us from evil; and to St. Teresa's Hospital for accommodation while in Hong Kong.

\section{REFERENCES}

Albee, A.L. and L. Ray, Correction factors for electron probe microanalysis of silicates, oxides, carbonates, phosphates and sulphates, Anal. Chem., 42, 1408-1414, 1970.

Allen, C.R., A.R. Gillespie, Y. Han, K.E. Sieh, B. Zhang, and C. Zhu, Red River and associated faults, Yunnan province, China: Quaternary geology, slip rates, and seismic hazard, Geol. Soc. Am. Bull., 95, 686-700, 1984.

Armijo, R., P. Tapponnier, J.L. Mercier, and T. Han, Quaternary extension in southern Tibet: Field observations and tectonic implications, J. Geophys. Res., 91, 13,80313,872, 1986.

Bell, T.H. and M.A. Etheridge, Microstructure of mylonites and their descriptive terminology, Lithos, 6, 337-348, 1973.

Bence, A.E. and A.L. Albee, Empirical correction factors for the electron microanalysis of silicates and oxides, $J$. Geol., 76, 382-403, 1968.

Berthé, D., P. Choukroune, and P. Jegouzo, Orthogneiss, mylonites and non coaxial deformation of granites: the example of the South Armorican shear zone, J. Struct. Geol., 1, 31-42, 1979a.

Berthé, D., P. Choukroune, and D. Gapais, Orientations preferentielles du quartz et orthogneissification progressive en regime cisaillant: l'exemple du cisaillement sudarmoricain, Bull. Mineral., 102, 265-272, 1979 b.

Bird, P., Lateral extrusion of lower crust from under high topography, in the isostatic limit, J. Geophys. Res., 96, 10,275-10,286, 1991.

Briais, A., Cinématique d'ouverture de la mer de Chine du Sud (NanHai). Implications pour la tectonique Tertiaire de l'Asie, PhD thesis, Univ. Paris 6, 1989.

Briais, A., P. Patriat, and P. Tapponnier, Updated interpretation of magnetic anomalies and seafloor spreading stages in the South China sea: Implications for the Tertiary tectonics of SE Asia, J. Geophys. Res., in press, 1993.

Bureau of Geology and Mineral Resources of Yunnan, Geological map of Yunnan, scale 1:500,000, 1983.

Cheng, Y., A cognitive basis and discussion on the nappe structure of Ailao Shan-Diancang Shan, Geol. Yunnan, 6, 291-297, 1987.

Cobbold, P. and H. Quinquis, Development of sheath folds in shear regime, J. Struct. Geol., 2, 119-126, 1980.

Dewey, J.F., Extensional collapse of orogens, Tectonics, 7, 1123-1139, 1988.

Dewey, J.F., S. Cande, and W. Pitman, Tectonic evolution of the India/Eurasia collision zone, Eclogae Geol. Helv. $8 \hat{2}, 717-734,1989$.

Dodson, M.H., Closure temperature in cooling geochronological and petrological systems, Contrib. Mineral Petrol., 40, 259-274, 1973.

Duan X. and Zheo H., The AilaoShan-Tengtiohe fracture, the subduction of an ancient plate, Acta Geol. Sin., 55, 258-266, 1981.

England, P. and G. Houseman, Extension during continental convergence, with application to the Tibetan plateau, J. Geophys. Res., 94, 17,561-17,579, 1989.

Escher, $A$. and J. Watterson,, Stretching fabrics, folds and crustal shortening, Tectonophysics, 22, 223-231, 1974.

Fan, C., The tectonic-metamorphic belt of Mt. Ailao in Yunnan province, Geol. Yunnan, 5, 281-291, 1986.

Fan, P.F., Outline of the tectonic evolution of southwestern China, Tectonophysics, 45, 261-267, 1978.

Ferry, J.M. and F.S. Spear, Experimental calibration of the partitioning of $\mathrm{Fe}$ and $\mathrm{Mg}$ between biotite and garnet, Contrib. Mineral. Petrol., 66, 113-117, 1978.

Fitz Gerald, J.D. and Hairrison T.M., Argon diffusion domains in K-feldspar I: Microstructures in MH-10, Contrib. Mineral Petrol., in press, 1993.

Ghent, E.D. and M.Z. Stout, Geobarometry and geothermometry of plagioclase-biotite-garnet-muscovite assemblages, Contrib. Mineral. Petrol., 76, 92-97, 1981.

Guo S., Zhang J., and $\mathrm{Li} X$., Fault displacement and recurrence intervals of earthquakes on the northern segment of the Honghe river fault zone, Seismol. Geal., 8,77-99,1986.

Harrison, T.M., Chen W., P.H. Leloup, F.J. Ryerson, and P. Tapponnier, An Early Miocene transition in deformation regime on the Red River Fault Zone, Yunnan, and its implications to Indo-Asian tectonics, J. Geophys. Res., 97, 7159-7182, 1992a.

Harrison, T.M., P. Copeland, W.S.F. Kidd, and A. Yin, Raising Tibet, Science, 225, 1663-1670, $1992 \mathrm{~b}$.

Harrison, T.M., O.M. Lovera, and M.T. Heizler, ${ }^{40} \mathrm{Ar} /{ }^{30} \mathrm{Ar}$ results for alkali feldspars containing diffusion domains with differing activation energy, Geochim. Cosmochim. Acta, 55, 1435-1448, 1991.

Helmcke, D., The Permo-Triassic "Paleotethys" in mainland Southeast-Asia and adjacent parts of China, Geol. Rundsch., 74, 215-228, 1985. 
Higgins, M.W., Cataclastic rocks, U.S. Geol. Surv. Prof. Pap., 687, 97 pp., 1971.

Hobbs, B., W. Means, and P. Williams, An Outline of Structural Geology, John Wiley, New York, 1976.

Hodges, K.V. and P.D. Crowley, Error estimation and empirical geothermomobarometry for pelitic shists, $A m$. Mineral., 70, 702-709, 1985.

Hodges, K.V. and F.S. Spear, Geothermometry, geobarometry and the $\mathrm{Al}_{2} \mathrm{SiO}_{5}$ triple point at Mt. Moosilauke, New Hampshire, Am. Mineral., 67, 1118-1134, 1982.

Hutchinson, C.S., The Paleo-Tethyan realm and Indosinian orogenic system of southeast Asia, in Tectonic evolution of the Tethyan Region, edited by A.M.C. Sengor, 585-643 pp., Academic, San Diego, Calif., 1989.

Klimetz, M.P., Speculation on the Mesozoic plate tectonic evolution of eastern China, Tectonics, 2, 139-166, 1983.

Lacassin, R. and M. Mattauer, Kilometer-scale sheath fold at Mattmark and implications for transport direction in the Alps, Nature, 316, 739-742, 1985.

Lacassin, R., P.H. Leloup, A. Briais, and P. Tapponnier, Bounds on strike-slip displacements along large Tertiary shear zones in SE Asia, Terra Abs., 6, 258, 1991.

Lacassin, R., P.H. Leloup, and P. Tapponnier, Shear strain estimate in large-scale shear-zones using restoration of boudinage structures example of tertiary SE-Asian shear zones, J. Struct. Geol., in press, 1993.

Leloup, P.H., Cinématique des déformations "Himalayennes" dans la zone de cisaillement crustale de l'Ailao Shan-Fleuve Rouge (Chine), $\mathrm{PhD}$ thesis, Univ. Paris, 1991.

Leloup, P.H. and J.R. Kienast, Thermobarometry in a Tertiary strike-slip shear zone: Evidence for shear heating?, Earth Planet. Sci. Lett., in press, 1993.

Leloup, P.H., P. Lacassin, P. Tapponnier, H. Maluski, J.R. Kienast, Zhong D., Liu X., Zhang L., and Zhong J., New evidence for Miocene left-lateral movement along the Red River shear zone (Yunnan, China), Eos Trans. AGU, $\boldsymbol{\gamma 1}_{1}$, $1617-1618,1990$.

Liu, X., U. Schärer, and P. Tapponnier, Timing of largescale strike-slip movements in the Dian Cang Shan and Ailao Shan shear belts, Yunnan, China, Eos Trans. $A G U$, 73 (14), Spring Meeting suppl., 310, 1992.

Lovera, O.M., F.M. Richter, and T.M. Harrison, The ${ }^{40} \mathrm{Ar} /{ }^{38} \mathrm{Ar}$ thermochronometry for slowly cooled samples having a distribution of diffusion domain sizes, $J$. Geophys. Res., 94, 17,917-17,935, 1989.

Lovera, O.M., F.M. Richter, and T.M. Harrison, Diffusion domains determined by ${ }^{30} \mathrm{Ar}$ released during step heating, J. Geophys. Res., 96, 2057-2069, 1991.

Lovera, O.M., M.T. Heizler, and T.M. Harrison, Argon diftusion domains in K-feldspar II: Kinetics properties of MH-10, Contrib. Mineral. Petrol., in press, 1993.

Lyons, J.B. and J. Snellenburg, Dating faults, Geol. Soc. Am. Bull., 82, 1749-1751. 1971.

Mattazer, M., Sur le mécanisme de la formation de la schistosité dans 1'Himalaya, Earth Planet. Sci. Lett., 28, 144$154,1975$.

McDougall, I. and T.M. Harrison, Geochronology and Thermochronology by the ${ }^{40}$ Ar ${ }^{9}{ }^{A}$ Ar Method, 212 pp., Oxford University Press, New York, 1988.

McFadden, P.L. and F.J. Lowes, The discrimination of mean directions drawn from Fisher distributions, Geophys. J. Astron. Soc., 67, 19-33, 1981.

McFadden, P.L. and M.W. McElhinny, Classification of the reversal test in paleomagnetism, Geophys. J. Int., 103, 725-729, 1990.

Mercier, J.L., R. Armijo, P. Tapponnier, E. Carey-Gailardis, and T.L. Han, Change from Tertiary compression to Quaternary extension in southern Tibet during the Inda-Asia collision, Tectonics, 6, 275-304, 1987.

Miller, D.S., P.F. Duddy, A.J. Hurford, and C.W. Naeser, Results of interlaboratory comparison of fission-track age standards: Fission-Track Workshop-1984, Nucl. Tracks, 10, 383-391, 1985.

Molnar, P. and P. England, Temperature, heat flux, and frictional stress near major thrust faults, J. Geophys. Res., 95, 4833-4856, 1990.
Peltzer, G. and P. Tapponnier, Formation and evolution of strike-slip faults, rifts, and basins during the India-Asia collision: An experimental approach, J. Geophys. Res., $93,15,085-15,117,1988$.

Quinquis, H., C. Audren, J.P. Brun, and P. Cobbold, Intense progressive shear in the Mle de Groix blue-schists and compatibility with subduction or obduction, Nature, 273, 43-45, 1978.

Richter, F.M., O.M. Lovera, T.M. Harrison, and P. Copeland, Tibetan tectonics from ${ }^{40} \mathrm{Ar} /{ }^{39} \mathrm{Ar}$ analysis of a single K-feldspar sample, Earth Planet. Sci. Lett., 105, 266-278, 1991.

Schärer, U., P. Tapponnier, R. Lacassin, P.H. Leloup, and D. Zhong, Intraplate tectonics in Asia: A precise age of Tertiary large-scale movement along the Ailao ShanRed River shear belt, China, Earth Planet. Sci. Lett., 97, 65-77, 1990.

Sengor, A.M.C., Tectonic subdivisions and evolution of Asia, Bull. Tech. Univ. Istanbul, 40, 355-438, 1987.

Sibson, R.H., Fault rocks and fault mechanisms, J. Geol. Soc. London, 133, 191-213, 1977.

Simpson, C. and S. Schmidt, An evaluation of shear criteria to deduce the sense of morements in sheared rocks, Geol. Soc. Am. Bull., 94, 1281-1288, 1983.

Spear, F.S and J.T. Cheney, A petrogenetic grid for pelitic schists in the system $\mathrm{SiO}_{2}-\mathrm{Al}_{2} \mathrm{O}_{3}-\mathrm{FeO}-\mathrm{MgO}-\mathrm{H}_{2} \mathrm{O}$, Contrib. Mineral. Petrol., 101, 149-164, 1989.

Spear, F.S and J. Selverstone, Quantitative P-T paths from zoned garnets: theory and tectonic applications, Contrib. Mineral. Petrol., 83, 348-357, 1983.

Spear, F.S, M.J. Kohn, F.P. Florence, and T. Menard, A model for garnet and plagioclase growth in pelitic schists: Implications for thermobarometry and P-T path determinations, J. Metamorph. Geol., 8, 683-696, 1990.

Spear, F.S, S.M. Peacock, M.J. Kohn, F.P. Florence, and T. Menard, Computer programs for petrologic P-T-t path calculations, Am. Mineral., 76, 2009-2012, 1991

Tapponnier, P., R. Lacassin, P.H. Leloup, U. Schärer, S. Ji, H. Wu, J. Zhong, L. Zhang, and X. Liu, The Ailao Shan/Red River metamorphic belt: Tertiary left-lateral shear between Indochina and South China, Nature, 343 , 431-437, 1990.

Tapponnier, P. and P.J. Molnar, Active faulting and tectonics of China, J. Geophys. Res., 82, 2905-2930, 1977.

Tapponnier, P., G. Peltzer, and R. Armijo, On the mechanics of the collision between India and Asia, in Collision Tectonics, edited by M.P. Coward and A.C. Ries, Geol. Soc. Spec. Publ. London, 19, 115-157, 1986.

Tapponnier, P., G. Peltzer, A.Y. Le Dain, and R. Armijo, Propagating extrusion tectonics in Asia: new insights from simple experiments with plasticine, Geology, 10 , 611-616, 1982.

Taylor, B. and D.E. Hayes, The tectonic evolution of the South China Basin, in The Tectonic and Geologic Evolution of Southeast Asian Seas and Islands, Geophys. Monogr. Ser., vol. 23, edited by D.E. Hayes, pp. 23-56, AGU, Washington D.C., 1980.

Taylor, B. and D.E. Hayes, Origin and history of the South China Basin, in The Tectonic and Geologic Evolution of Southeast Asian Seas and Islands, Part 2, Geophys. Monogr. Ser., vol. 27, edited by D.E. Hayes, pp. 9-104, AGU, Washington D.C., 1983.

Van Den Driessche, J. and J.P. Brun, Rolling structures at large shear strain, J. Struct. Geol., 9, 691-704, 1987.

Wagner, G.A., G.M. Reimer, and E. Jager, Cooling ages derived by apatite fission-track, mica $\mathrm{Rb}-\mathrm{Sr}$ and $\mathrm{K}-\mathrm{Ar}$ dating: The uplift and cooling history of the central Alps, Mer Inst. Geol. Mineral. Univ. Padova, 30, 27 pp., 1977.

Wang, E. and J.J. Chu, Collision tectonics in the Cenozoic orogenic zone bordering China, India and Burma, Tectonophysics, 147, 71-84, 1988.

Wu, Q., Zu J., Xie Y., and Wang D., Characteristics of geothermal field in Yunnan region, Seismol. Geol., 10, $177-183,1988$.

Chen W. and Li Q., Institute of Geology, State Seismological Bureau, Beijing, 100029, People's Republic of China. 
T. M. Harrison, Department of Earth and Space Sciences and Institute of Geophysics and Planetary Physics, University of California, Los Angeles, CA 90024, U.S.A.

P.H. Leloup, P. Tapponnier, and R. Lacassin, Institut de Physique du Globe de Paris, 4, place Jussieu, 75252 Paris Cedex 05, France.

F.J. Ryerson, Institute of Geophysics and Planetary
Physics, Lawrence Livermore National Laboratory, Livermore, CA 94550, U.S.A.

(Heceived June 8, 1992;

revised November 24 1992;

accepted November 24, 1992.) 